\title{
The Manchu-language archives of the Qing Dynasty and the origins of the palace memorial system
}

\section{Citation}

Elliott, Mark C. 2001. The Manchu-language archives of the Qing Dynasty and the origins of the palace memorial system. Late Imperial China 22, no.1: 1-70. doi:10.1353/late.2001.0002.

\section{Published Version}

10.1353/late.2001.0002

\section{Permanent link}

http://nrs.harvard.edu/urn-3:HUL.InstRepos:27409233

\section{Terms of Use}

This article was downloaded from Harvard University's DASH repository, and is made available under the terms and conditions applicable to Other Posted Material, as set forth at http:// nrs.harvard.edu/urn-3:HUL.InstRepos:dash.current.terms-of-use\#LAA

\section{Share Your Story}

The Harvard community has made this article openly available.

Please share how this access benefits you. Submit a story.

\section{Accessibility}




\title{
THE MANCHU-LANGUAGE ARCHIVES OF THE QING DYNASTY AND THE ORIGINS OF THE PALACE MEMORIAL SYSTEM
}

\author{
Mark C. Elliott
}

One of the more noteworthy recent trends in scholarship on late imperial Chinese and Inner Asian history is the growing recognition of the importance of Manchu as a research language. This change owes principally to two developments. One is the opening, beginning in the late 1970s, of the First Historical Archives of China (FHA) to general scholarly use. This liberalization inaugurated an ongoing process of discovery that has enabled historians to gain a first-hand familiarity with the variety and nature of the more than $10,000,000$ items on deposit there, most of which are from the Qing period (1636-1912). ${ }^{1}$ Fuller information has emerged concerning that portion of the Qing archives not in the Chinese script - meaning primarily, though not exclusively, materials in Manchu - which puts us in a better position to appreciate the significance of these sources. In consequence, opinion has shifted away from the old view that Manchu materials are of little relevance for Qing history after $1644,{ }^{2}$ toward the view that documents written in a language so

\footnotetext{
1 Research for this article was made possible by grants from the Committee on Scholarly Communication with China, the American Council of Learned Societies/Social Science Research Council, and the Japan Society for the Promotion of Science. The author would like to express his thanks as well for invaluable assistance rendered on many occasions by staff at the First Historical Archives (Beijing), the Liaoning Provincial Archives (Shenyang), and the National Palace Museum Archives (Taipei). Special appreciation also to Beatrice S. Bartlett and Kato Naoto for advice and comments on preliminary versions of this essay.

This is the official figure used by the First Historical Archives in its own publications. See, for instance, First Historical Archives, Zhongguo diyi lishi dang'anguan guancang dang'an gaishu (Beijing: Dang'an chubanshe, 1985), 3, 27. Note that an "item" (Ch. jian) says nothing about the actual size or volume of a document. See Endymion Wilkson, ed., Chinese History: A Manual, rev. ed. (Cambridge: Harvard University Asia Center, 2000), 900, n2. Chapter 50 of this manual offers an excellent general introduction to the Chinese-language archives of the Qing; a partial listing of Manchu-language materials is found on pp. 926-29.

2 This view was advanced by none other than Joseph F. Fletcher (writing in 1973): "Almost all Manchu source material, even from the earliest period, was carried over in one form or another into Chinese. For historians of the middle and late Ch'ing, Manchu records can be useful, but they are not necessary." This from his article, "Manchu Sources," in Donald Leslie, Colin Mackerras, and Wang Gungwu, eds., Essays on the Sources for Chinese History (Canberra: ANU Press, 1973), 145.
}

Late Imperial China Vol. 22, No. 1 (June 2001): 1-70

(C) by the Society for Qing Studies 
different from Chinese as Manchu might, in fact, offer valuable new insights into the post-conquest period after all. ${ }^{3}$

The second factor that helps explain the shift in the appreciation of Manchu relates to larger changes in late twentieth century intellectual currents, especially the inclination to question dominant historical narratives (what are sometimes called "hegemonizing discourses") and to rethink the past from the viewpoints of those, such as minorities, women, and outcasts, who have been marginalized historiographically. In part as a result of these trends, and in part because of the social and political landscape of the contemporary world, ethnicity (along with gender, sexuality, and crime) has become an urgent subject of scholarly investigation. For China, this has produced a new literature in search of a fresh understanding of the role of non-Han peoples in Chinese politics and society, a literature, moreover, which has intersected with concurrent rethinking of the development of the ideology of the modern Chinese nation-state, invested as it is with various notions of Han superiority. ${ }^{4}$ As China's last imperial masters, the alien Manchus have thus become an obvious focus of interest: not only were they minority rulers, but the empire they built - the greatest continental empire since the time of Cinggis - is seen as the predecessor, if not the blueprint, of the vast polyethnic state that China has

\footnotetext{
3 The first Western scholar to come forward with such a reassessment was Beatrice S. Bartlett. In an important 1985 article, Bartlett first summed up current opinion ("The received wisdom on the Manchu language archives of the Ch'ing dynasty has been that historians of the Ch'ing have little need either to learn Manchu or to use Manchu materials for research on historical subjects. Learning Chinese will suffice, the argument goes, because the Ch'ing dyarchical principle guaranteed that everything written in Manchu was also recorded in Chinese") and then showed that it was wrong: "In contrast with what has hitherto been thought, ... many unique Manchu documents, never translated into Chinese, were produced in the middle and even the late Ch'ing. Future Ch'ing historians may well find the study of Manchu worthwhile." See "Books of Revelations: The Importance of the Manchu Language Archival Record Books for Research on Ch'ing History," Late Imperial China 6.2 (December 1985), 33. Influenced by news of Bartlett's findings, by 1981 Fletcher had changed his mind about the importance of Manchu: "A Ch'ing scholar who wants to do first-class work in the archives must, from now on, learn Manchu and routinely compare the Manchu and Chinese sources for their topics of research" ("Review of Walter Simon and Howard G.H. Nelson, Manchu Books in London: A Union Catalogue," Harvard Journal of Asiatic Studies 41.2 [December 1981], 653-656). A comprehensive statement of the value of Manchu for research on the Qing is found in Pamela Kyle Crossley and Evelyn S. Rawski, "A Profile of the Manchu Language in Ch'ing History," Harvard Journal of Asiatic Studies 53.1 (June 1993), 63-102.

4 On ethnicity in China, see, inter alia, Frank Dikötter, The Discourse of Race in Modern China (Stanford: Stanford University Press, 1992); Stevan Harrell, ed., Cultural Encounters on China's Ethnic Frontiers (Seattle: University of Washington Press, 1995); Melissa J. Brown, ed., Negotiating Ethnicities in China and Taiwan (Berkeley: Institute of East Asian Studies, 1996); and Pamela Kyle Crossley, Helen F. Siu, and Donald Sutton, eds., Empire at the Margins: Culture, Ethnicity, and Frontier in Early Modern China (Berkeley and Los Angeles: University of California Press, forthcoming).
} 
become today. ${ }^{5}$ Learning the Manchu language has thus come to be perceived as a vital tool for getting to know the Manchus and their empire better.

The burgeoning interest in things Manchu is not without precedent. Sinology, in its infancy, was weaned on Manchu. Three hundred years ago the language was seen as a crucial tool for understanding the Chinese classics, many of which had been translated by teams of scholars working at the pleasure of the court in the seventeenth and eighteenth centuries. The Jesuit missionaries whose labors laid the foundations of the West's study of China were unanimously of the opinion that the grammatical structures and signifiers of Manchu clarified much that was obscure in the antique Chinese language and that Manchu was more "logical" and easier to learn than Chinese. Moreover, they found a knowledge of Manchu extremely useful in daily life in mid-Qing Beijing. ${ }^{6}$ But Manchu's early prominence in the field declined markedly in the nineteenth century, when Protestant missionaries and colonialists took the place of Jesuit polymaths at the forefront of Chinese studies. James Legge, for instance, was of the opinion that Manchu translations, however expert, were biased, as they reflected official post-Song interpretations. ${ }^{7}$ That Legge knew no Manchu may have made it easier for him, of course, to espouse this position. Nonetheless, his view carried the day and it has been a century since any translator has bothered to look for help from the Manchu versions of the Four Books, the Five Classics, or any other Chinese text. ${ }^{8}$ The collapse of the Qing dynasty in 1912 further weakened the case for learning Manchu, and by 1930, when Erich Hauer wrote his treatise, "Why the Sinologue Should Study Manchu," he was lamenting the language's slide into almost complete obscurity. ${ }^{9}$ In the

\footnotetext{
5 This line of thinking is implicit in much of the work by Chinese scholars, who tend to frame their discussions of the Qing with the same phrase (tongyi de duominzu guojia, lit., "unified polyethnic state") that is used for the People's Republic of China. Elaborated in the work of Kataoka Kazutada, Shinchō Shinkyō tōchi kenkȳū (Tokyo: Yuzankaku Press, 1991) and Ishibashi Takao, "Manju ōchōron: Shinchō kokkaron josetsu," in Hamashita Takeshi et al., eds., Min-Shin jidaishi no kihon mondai (Tokyo: Kyūko shoin, 1997), the theme is pursued explicitly also in Evelyn S. Rawski, who refers to the Qing as a "multiethnic" and "multicultural" state. See her The Last Emperors: A Social History of Qing Imperial Institutions (Berkeley and Los Angeles: University of California Press, 1999), 2, 200.

${ }^{6}$ Mark C. Elliott, The Manchu Way: The Eight Banners and Ethnicity in Late Imperial China (Stanford: Stanford University Press, 2001), 292 and note.

${ }^{7}$ See Legge's reply to criticism that he had not availed himself of existing Manchu translations, contained in the preface to The Chinese Classics, Vol. III: The Shoo King, or The Book of Historical Documents (Hong Kong: London Missionary Society, 1865), vii.

${ }^{8}$ One of the last to do so, Erwin von Zach, admitted that Manchu offered only "unreliable assistance" (though it could sometimes still be helpful) and that therefore "the study of Manchu in its connexion with Chinese should henceforward be considered from a totally different standpoint," arguing instead for the importance of knowing Manchu "for its own sake" as a historical language. Erwin von Zach, "Manchurian Translation of Lao-tzu's Tao-tê-ching," The China Review 25 (1900-1901), 158. A recent study reveals, however, that excavation of these Manchu translations can be extremely fruitful in tracing the transmission of texts. See Laura E. Hess, "The Manchu Exegesis of the 'Lunyu," Journal of the American Oriental Society 113.3 (July-September 1993), 402-17.
}

9 Bulletin of the North China Branch of the Royal Asiatic Society 61 (1930), 156-164. 
world of post-war Sinology, very few students of Qing history anywhere, including China (the language had virtually disappeared by then as a living tongue), learned Manchu or were even encouraged to do so. The handful who did, mostly in Japan and Germany, concentrated their research primarily on the pre-conquest period, though there are some notable exceptions (such as Chuang Chi-fa, working in Taiwan).

Given that the current interest of Western scholars in Manchu language and history represents the reemergence of a field whose last heyday was in the eighteenth century, it should not come as a surprise that recent findings confirm what the Jesuits already knew then: that the Manchus were not "Chinese" and that Qing politics and society were ethnically complex. ${ }^{10}$ What is somewhat surprising is that despite the rise of the "New Manchu History" and a renewed emphasis on the importance of Manchu sources, very few Qing historians in fact employ Manchu materials in their research. ${ }^{11}$ The reasons for this are not hard to find. Apart from habitual neglect and a paucity of opportunities for instruction in Manchu, one basic problem is that, notwithstanding recent progress in this regard, the Manchu archives remain relatively little known. The goal of this essay is thus to introduce the principal archival sources available in the Manchu language that are useful for research in Qing history. I begin by describing the disposition and typology of extant Manchu archives accessible in China today, published as well as unpublished. In the second part of the essay I take up in detail one particularly valuable type of source, the Manchu palace memorials. As a way of demonstrating the sorts of things these documents have to tell us, I review the origins of the palace memorial system, regarded as one of the most important Qing institutional innovations, in the light of Manchu materials that have lately been discovered.

\footnotetext{
10 This is the emphasis of much of the new research on Manchu history. Notable books in this area include Pamela Kyle Crossley's Orphan Warriors (Princeton: Princeton University Press, 1990) and $A$ Translucent Mirror (Berkeley and Los Angeles: University of California Press, 1999), Edward J.M. Rhoads, Manchus and Han (Seattle: University of Washington Press, 2000), as well as Rawski, The Last Emperors, and Elliott, The Manchu Way, already mentioned. In addition, a number of studies published since the late 1980s have called attention to Manchu-Han ethnic tension in the Qing as an unmistakable, if sometimes intangible, element in Qing politics that cannot be overlooked. See, for instance, Beatrice S. Bartlett, Monarchs and Ministers (Berkeley and Los Angeles: University of California Press, 1990), Philip A. Kuhn, Soulstealers: The Chinese Sorcery Scare of 1768 (Harvard: Harvard University Press, 1990), and James Polachek, The Inner Opium War (Cambridge: Harvard Council on East Asian Studies, 1992).

11 Beatrice Bartlett (in Monarchs and Ministers) and Evelyn Rawski (in The Last Emperors) make use of a limited number of Manchu materials, as the notes to their work shows. More extensive use is found in Nicola Di Cosmo, "Manchu Shamanic Ceremonies at the Qing Court," in Joseph McDermott, ed., State and Court Ritual in China (Cambridge: Cambridge University Press, 1999), 352-98, Xiangyun Wang, "The Qing Court's Tibet Connection: Lcang skya Rol pa'I rdo rje and the Qianglong Emperor," Harvard Journal of Asiatic Studies 60.1 (June 2000), 125-163, and in Elliott, The Manchu Way.
} 
A review such as this one is bound to have its limitations and omissions. My hope in presenting such information is not to be encyclopedic, but to stimulate interest and advance research in Manchu-language sources and the Inner Asian dimension of Qing rule onto which they open a unique window. Much work remains to be done before we can know to what extent Manchu materials will revolutionize our understanding of the Qing period.

\section{Overview of Qing-period Manchu-language Archives}

The materials introduced below include mainly archival materials from after the 1644 Qing conquest of China. Excluded are pre-conquest archives such as the Jiu Manzhou dang and the Manwen laodang (Manbun rōtō), which are well described in the literature. ${ }^{12}$ While the emphasis is on unpublished materials, I have also listed published facsimiles, transcriptions, and translations (mostly into Chinese) of Manchu archival documents - by which I mean original records compiled or issued by, or at the command of, Qing governmental offices that were not intended for wider circulation. I have therefore chosen to exclude works of a primarily philosophical, literary, religious, didactic, or linguistic nature (whether originally in Manchu or translated from Chinese), along with official chronicles and compendia such as the Veritable Records (Da Qing lichao shilu), the Collected Institutes of the Qing (Da Qing huidian), imperial instructions (shengxun) and military histories (fanglue). I am, of course, fully aware that such materials are of great importance to historians. But as the majority of such works were printed in the Qing, they are not, strictly speaking, archival in nature, and descriptions of them are available elsewhere. ${ }^{13}$ I also exclude examination materials and private genealogies,

\footnotetext{
12 Jiu Manzhou dang (Tongki fuka akū hergen-i dangse), in unpointed script, and Manwen laodang (Tongki fuka sindaha hergen-i dangse), in pointed script. The bibliography on these items is extensive. The best introduction is Kanda Nobuo, "From Man-wen lao-tang to Chiu Man-chou tang," Memoirs of the Research Department of the Tóyō Bunko 38 (1980), 71-94. See also the summary in Crossley and Rawski, "A Profile," 67. To their list of important pre-conquest Manchu materials should be added the documents translated in Qingchu neiguoshiyuan Manwen dang 'an yibian (see below) and those described in Tatiana A. Pang and Giovanni Stary, New Light on Manchu Historiography and Literature: The Discovery of Three Documents in Old Manchu Script (Wiesbaden: Otto Harrassowitz, 1998).

13 The major catalogues of printed Manchu books are Li Teh-ch'i, Guoli Beiping tushuguan gugong bowuyuan tushuguan Manwen shuji lianhe mulu (Beiping: Palace Museum, 1933); Nicholas Poppe, Leon Hurvitz, and Hidehiro Okada, Catalogue of the Manchu-Mongol Section of the Töyō Bunko (Tokyo: Tōyō Bunko, 1964); Walter Simon and Howard G.H. Nelson, Manchu Books in London (London: British Museum, 1977); Jeanne-Marie Puraiymond, Catalogue du fonds Mandchou (Paris: Bibliothèque Nationale, 1979); M.P. Volkova, Opisanie man' chzhurskikh ksilografov instituta vostokovedeniia AN SSSR (Moscow: Academy of Sciences, 1988); Huang Runhua and Qu Liusheng, eds., Quanguo Manwen tushu ziliao lianhe mulu (Beijing: Shumu chubanshe, 1991); and Matsumura Jun, A Catalogue of Manchu Materials in the Library of Congress: Xylographs, Manuscripts, Archives (Tokyo: Toyo Bunko, 1999).
} 
though I include official genealogies compiled under the auspices of the Eight Banners. Finally, I have found it necessary to limit this introduction to materials in the most important Chinese depositories, namely the First Historical Archives in Beijing, the Third Historical Archives in Shenyang, and, in Taipei, the National Palace Museum (NPM) Archives and Academia Sinica. With a few exceptions, archival holdings in other Chinese collections (such as in Dalian, Changchun, and Harbin), and in Japan, Mongolia, Europe, and North America are not considered; they may be located by consulting the individual catalogues of those collections. ${ }^{14}$

\section{Published Materials: Facsimiles and Transcriptions}

Relatively little of the Manchu archives has been published. Among such materials, of first importance are those items published in facsimile or transcription, which furnish scholars copies of the original documents, or at least provide the original language. For the post-conquest era, one of the earliest such publications was issued under the auspices of the Manchukuo government (which was also responsible for issuing the first reprint of the entire Qing Veritable Records, based on the version kept in the Mukden imperial palace):

Shunzhi nianjian dang (Archives from the Shunzhi years). Xinjing [Changchun]: Manchukuo National Central Library, 1942. 71 documents dating from 1647-1661, from the collection in the Mukden Imperial Household Department, discovered in the Mukden (a.k.a. Shengjing, Fengtian, Shenyang) palace complex in 1925 by Jin Liang. Includes a complete transcription and a running translation into Japanese. A Chinese translation (without the transcription) was published in volume 2 of Qingshi ziliao (Beijing: Zhonghua shuju, 1981.)

Of facsimiles of Manchu texts, most voluminous and best known are the Manchu palace memorials published by the National Palace Museum in Taiwan. These include the following:

Gongzhongdang Kangxi chao zouzhe (Secret palace memorials of the Kangxi reign). 9 volumes. Taipei: National Palace Museum, 1975-1977. Volumes 8 and 9 contain Manchu memorials only.

Gongzhongdang Yongzheng chao zouzhe (Secret palace memorials of the Yongzheng reign). 32 volumes. Taipei: National Palace Museum, 1977-1980. Volumes 28-32 contain Manchu memorials only.

14 Collections of Manchu books and archives are found in many places. A comprehensive list of catalogues is found in Giovanni Stary, Manchu Studies: An International Bibliography (Wiesbaden: Kommissionsverlag Otto Harrassowitz, 1990), vol. 1, 1-15. 
Gongzhongdang Qianlong chao zouzhe (Secret palace memorials of the Qianlong reign). 75 volumes. Taipei: National Palace Museum, 1982-1988. Volume 75 contains Manchu memorials only.

More on these materials appears in the section on palace memorials below. Note that the Chinese memorials (not the Manchu) from the first two series were later reprinted together with memorials held in the FHA: Kangxi-era memorials in Kangxi chao Hanwen zhupi zouzhe huibian, 8 volumes (Beijing: Dang'an chubanshe, 1984), Yongzheng-era memorials in Yongzheng chao Hanwen zhupi zouzhe huibian, 40 vols. (Hangzhou: Jiangsu guji chubanshe, 1989).

Nian Gengyao zouzhe zhuanji (The memorials of Nian Gengyao). 3 volumes. Taipei: National Palace Museum, 1971. Contains reproductions of the collected memorials of Nian Gengyao (d. 1726), who achieved considerable fame for his military exploits on the western frontier before being put to death by the Yongzheng emperor. Vols. 1 and 2 contain 90 Chinese memorials, 194 Manchu memorials, 9 letters in Manchu, and 40 bilingual edicts. Volume 3 has reproductions of Nian's already-published Chinese memorials. All of the Manchu memorials were translated and published in Ji Yonghai, Li Pansheng, and Xie Zhiyu, trans., Nian Gengyao Man-Han zouzhe yibian (Tianjin: Tianjin guji chubanshe, 1995).

Taiwan-based Manjurists Chuang Chi-fa and Ch'en Chieh-hsien have both written extensively about the Manchu archives and have published a number of editions of selected portions of archival materials, most with annotations and translations:

Qingdai Zhun-ga-er shiliao chubian (Preliminary compilation of Qing historical materials on the Dzungars). Chuang Chi-fa, ed. Taipei: Wenshizhe chubanshe, 1977. In this volume, Chuang brings together a number of memorials and edicts from the 1690s, when the Kangxi emperor led three campaigns against the Dzungar leader, Galdan. The text includes the original Manchu (rewritten in Manchu script and in romanized transcription), together with a running translation and a full translation into Chinese. In addition, Chuang also compares the original documents with the official accounts of the campaign published in the Veritable Records and the Pingding shuomo fanglue, showing among other things that the date of Galdan's death was altered to coincide with the advance of the emperor's army.

Sun Wencheng zouzhe (The memorials of Sun Wencheng). Chuang Chi-fa, ed. Taipei: Wenshizhe chubanshe, 1978. Sun, of the Manchu Bordered Yellow Banner and a contemporary of Li Xu and Cao Yin, was supervisor of the imperial manufactory in Hangzhou. Chuang has assembled all of Sun's Manchu-language memorials from the Taipei collection (many of them heavily 
rescripted by the Kangxi emperor) and translated them into Chinese, with annotations. Sun's Chinese-language memorials are also appended.

Manwen Qing shilu yanjiu (Studies of the Manchu-language version of the Qing Veritable Records). Ch'en Chieh-hsien. Taipei: Dahua shuju, 1978.

Manwen Qing benji yanjiu (Studies of the Manchu-language versions of the imperial biographies). Ch'en Chieh-hsien, ed. Taipei: Mingwen shuju, 1981. Both this and the preceding study compare the different redactions of the Manchu-language versions of their respective texts. Each also offers a comparison of the Manchu and Chinese versions. Selected excerpts of the Manchu Veritable Records and imperial biographies are transcribed and translated into Chinese. Facsimiles of those sections are also provided.

Man-Han Yiyulu jiaozhu (Annotated record of a journey to the Torguts). Chuang Chi-fa, ed. Taipei: Wenshizhe, 1983. A facsimile of the original text written by Tulišen (1667-1740) and published in 1723. Chuang has also included a romanization and a Chinese translation.

Yongzheng chao Man-Han hebi zouzhe jiaozhu (Collated Manchu-Chinese bilingual memorials of the Yongzheng reign). Chuang Chi-fa, ed. and trans. Taipei: Wenshizhe chubanshe, 1984. Contains 44 bilingual memorials from the first year of the Yongzheng reign (1723). The Manchu is reproduced in facsimile, with a romanized transcription and the original Chinese text printed below. The notes at the end point out many of the differences between the two versions of documents that are ostensibly the same.

The Manchu Palace Memorials. Ch'en Chieh-hsien. Taipei: Linking Publishing, 1987. Presents facsimiles, romanizations, and English translations of fifteen palace memorials from the Kangxi reign. Seven of these are from Sun Wencheng (see above); the rest pertain to the Galdan campaigns and the issue of the heir apparent. Also contains an informative introduction to the value of the Manchu palace memorials. A Chinese-only version was published as Manzhou dang'an ziliao (Archival materials in Manchu) (Taipei: Lianjing chuban gongsi, 1988).

Xie Sui "Zhigong tu" Manwen tushuo jiaozhu (Annotated edition of the Manchu annotations on Xie Sui's Zhigong tu). Chuang Chi-fa, ed. Taipei: National Palace Museum, 1989. Though not strictly archival in nature, Chuang's reproduction and translation of the Manchu commentary that accompanied this version of the Zhigong tu (in 4 juan; compiled in 1751 and subsequently added to until 1790) make this rare and valuable resource, with its beautiful color illustrations, available to historians. The introduction offers a number of examples of differences between the Chinese and Manchu annotations, pointing out the comparative ease of understanding the more plainly written Manchu text. The main text provides a facsimile of 301 of the original Manchu legends accompanying the illustrations, plus a romanized transcription as well as the Chinese characters. 
Gugong Taiwan shiliao gaishu (General description of Taiwan historical materials). Chuang Chi-fa, gen. ed. Taipei: National Palace Museum, 1995. Contains some memorials of Mamboo (Man-bao), governor of Fujian from 1711-1715 and governor-general of Fujian and Zhejiang from 1715-1725.

Facsimiles of rare Manchu translations of Buddhist texts have for the first time become available recently from the NPM holdings in Taiwan. Though not strictly archival, they nonetheless deserve mention:

Guoli gugong bowuyuan diancang Dazangjing Manwen yiben yanjiu (A study of the Manchu translation of the Tripitaka housed in the National Palace Museum). Chuang Chi-fa, ed. Taipei: National Palace Museum, 1991. In 1772 the Qianlong emperor commissioned the translation of the Buddhist canon into Manchu. Twenty-eight years later the immense project was complete, in an edition totaling 2,466 fascicles in 108 cases (han). 76 of these cases are now in the Palace Museum in Beijing, and 32 in the National Palace Museum in Taipei. This volume contains the photographic reproduction of one sutra from the latter collection, together with romanization and a translation into Chinese.

Man-Hanwen Dizang pusa benyuan jing jiaozhu (Redacted and annotated texts of the Sutra of the Original Vows of the Bodhisattva Ksitigarbha, in Manchu and Chinese). Pan Shubi, ed. Taipei: National Palace Museum, 1995. Contains the facsimiles of seventeen sutras from case no. 91 of the Manchu translation of the Buddhist canon (see above), along with a running romanization and the Chinese version of the same text, plus a glossary.

An important collection of documents pertaining to the Bordered Red Banner was published by the Seminar on Manchu History of the Toyo Bunko. Though as they are held in a Japanese collection these publications also fall outside the scope of this list, I include them because of their importance:

Jōkōkitō: Yōseichō (Bordered Red Banner archives, Yongzheng reign). Kanda Nobuo, Matsumura Jun, Okada Hidehiro, and Hosoya Yoshio, eds. Tokyo: Tōō Bunko, 1972. Contains transcriptions of 54 documents from the Yongzheng reign (14 from 1723-25, 30 from 1732-34) pertaining to miscellaneous issues of Eight Banner administration, including personnel and finance. A complete Japanese translation is appended.

Jōkōkitōo: Kenryūchō (Bordered Red Banner archives: Qianlong reign 1). Kanda Nobuo, Matsumura Jun, Okada Hidehiro, and Hosoya Yoshio, eds. Tokyo: Tōyō Bunko, 1983. Contains transcriptions of 126 documents from the first part of the Qianlong reign, covering the years 1738-1764. Like the preceding item, this is a valuable source for information on banner administration in the capital and garrisons, with much detail on succession to company captaincies. Summaries of document subjects precede the main text. There is no Japanese translation. 
Jōkōkitō: Kenryūchō (Bordered Red Banner archives: Qianlong reign 2). Kanda Nobuo, Matsumura Jun, Hosoya Yoshio, Ishibashi Takao, Katō Naoto, and Nakami Tatsuo, eds. Tokyo: Tōyō Bunko, 1993. Contains transcriptions of 131 documents from the second part of the Qianlong reign, covering the years 1766-1783. Similar in content and format to the immediately preceding item.

An unauthorized Chinese translation of the first item is found in Liu Housheng trans., Qing Yongzheng chao xianghongqidang (Changchun: Dongbei shifan daxue chubanshe, 1985); the authorized translation (first two volumes only) is Guan Jialu trans., Yong-Qian liangchao xianghongqidang (Shenyang: Liaoning renmin chubanshe, 1987). Neither contains the Manchu transcription. A complete index and user's guide to the Bordered Red Banner archives in the Toyo Bunko is now in preparation, which will also contain the transcriptions of 88 more documents from the last years of the Qianlong reign.

Beginning in the 1980s, portions of the Manchu archives have begun to emerge in published form from mainland collections, greatly increasing historians' awareness of the importance of Manchu materials and facilitating their use. While most of these publications consist solely of translations, a small number include transcriptions of the original text, making them suitable for scholarly use. Among these are:

Suijun xingji yizhu (Manchu title: Beye-i cooha bade yabuha babe ejehe bithe) (A record of my military exploits). Ji Yonghai, ed. and trans. Beijing: Zhongyang minzu xueyuan chubanshe, 1987. A first-hand account by Dzengseo, a low-ranking Manchu officer, of his experiences as a soldier in the suppression of the Rebellion of the Three Feudatories from 1680-1682. From a manuscript in the library of the Central Minorities University, Beijing. Of the original four juan, only the final juan is extant. Includes translation, transcription with running translation, and facsimile of the text.

Cing gurun-i dangse ci sonjome banjibuha Sibe-i suduri mutun (The historical development of the Sibe as selected from the Qing archives). 2 volumes. Urumqi: Xinjiang renmin chubanshe, 1987. This set of 389 documents, covering the period from the late sixteenth through the late nineteenth centuries, relates to the history of the Sibe people, their formation into companies in the Eight Banners, their migration to Xinjiang in the 1760s, and subsequent life on the frontier. Published in parallel 2-volume sets, one in the original Manchu and the other in Chinese translation (see under Published materials: Translations).

Finally, it is worth mentioning the transcription and translation of some nineteenth-century Manchu memorials from Xinjiang: 
Reports from the Northwest: A Selection of Manchu Palace Memorials from Kashgar, 1806-1807. Nicola Di Cosmo, ed. and trans. Papers on Inner Asia 25. Bloomington: Indiana University Research Institute for Inner Asian Studies, 1993. Presents the transcription, annotated translation, and facsimile of drafts of ten memorials sent in 1806-07 by Qing officials in Kashgar.

In addition to the above, transcriptions of individual Manchu-language documents, inscriptions, etc., may be found in doctoral dissertations and a range of periodical publications, including Lishi dang'an (Beijing), Manxue yanjiu (Beijing), Minzu yanjiu (Beijing), Gugong bowuyuan yuankan (Beijing), Manzu yanjiu (Shenyang), Gugong wenxian (Taipei), Manzokushi kenky_ ts_shin (Tokyo), Aetas Manjurica (Wiesbaden), Zentralasiatische Studien (Bonn), and Saksaha (Portland). Manchu materials have also been translated in the Qingdai dang'an shiliao congbian series (14 volumes; 1978-1990), published by the First Historical Archives and the Qingshi ziliao series (7 volumes; 1980-1989), published by the Chinese Academy of Social Sciences. For reasons of space, no attempt is made here to include this bibliography.

\section{Published materials: Translations}

Among the large number of publications from the Manchu archives that have appeared in recent years, most provide only translations into Chinese, with no reproduction or transcription of the original text. While such translations have a certain utility, the absence of the Manchu original in any form significantly limits their value to scholars. Particularly as in most cases no effort is made to render personal names according to their standard graphs, they are not to be relied on for identification of individuals. The list below proceeds in chronological order by date of publication. ${ }^{15}$

Youguan Da-hu-er E-lun-chun yu Suo-lun zu lishi ziliao (Historical materials relating to the Dagur, Oroqen, and Solon peoples). 2 volumes. Neimeng dongbei shaoshu minzu shehui lishi diaocha zu, Neimenggu zizhiqu Da-woer lishi yuyan wenxue xuehui, comp. Hohhot (?): 1958; repr. ed. 1985. Contains an unusual assortment of Qing-era documents relevant to the Daghur, Oroqen, and Solon minority nationalities. The origin of these materials is not stated, but close inspection (and the reproduction in vol. 2 of fragments in Manchu script) make it clear that these are translations into Chinese from Manchu.

Guanyu Jiangning zhizao Caojia dang'an shiliao (Cao family archives relating to the Nanjing factories). Beijing: Zhonghua shuju, 1975. A collection

15 This list omits specialized translations on science, medicine, and natural history, some of which also contain materials translated from Manchu. 
of 195 documents relating to the different members of the Cao family (Cao $\mathrm{Xi}$, Cao Yin) who were charged with supervision of the imperial manufactory at Nanjing. Approximately 60 of these items are translations from Manchu.

Qingdai Zhong-E guanxi dang'an shiliao xuanbian (Selected compilation of archival materials on Sino-Russian relations in the Qing). Series 1. 2 volumes. First Historical Archives, comp. and trans. Beijing: Zhonghua shuju, 1981. Invaluable resource containing translations of 285 Shunzhi-, Kangxi-, and Yongzheng-era documents from the E-luo-si dang, part of the Grand Secretariat Manchu archives in Beijing (see below). The majority of these are translations from original Manchu documents, but there are also Chinese translations of the Manchu translations of Russian and Mongolian documents.

Kangxi tongyi Taiwan dang'an shiliao xuanji (Selected archival materials on the unification of Taiwan under the Kangxi emperor). First Historical Archives, comp., and trans. Fuzhou: Fujian renmin chubanshe, 1983. Contains 184 documents from 1662-1684, of which 25 (nos. 3-26, 36-37) are translations from Manchu originals in the Miben dang archive, in the First Historical Archives (see below). All pertain to the prolonged battle with the Zheng regime for control of Taiwan and the Fujian coast.

Sanxing fudutong yamen Manwen dang'an yibian (Translated compilation of Manchu archives from the Sanxing garrison). Liaoning Provincial Archives, et al., comp. and trans. Shenyang: Liaoshen shushe, 1984. The Liaoning Provincial Archives possesses some 20,000 documents that originated from the Eight Banner garrison at Sanxing, in modern Heilongjiang province. This volume presents 179 documents by subject (e.g., tribute items, gifts to native peoples), dating from between 1743-1906. 118 of these are translations from Manchu documents.

Zheng Chenggong dang 'an shiliao xuanji (Selected compilation of historical archives on Zheng Chenggong). Xiamen University Taiwan Research Institute and First Historical Archives, comp. and trans. Fuzhou: Fujian renmin chubanshe, 1985. Contains 186 documents from between 1647 and 1662, of which 13 (nos. 174-186) are in Manchu. All deal with Qing efforts to deal with the resistance led by Zheng Chenggong (Koxinga).

Shengjing xingbu yuandang (The original archives of the Shengjing Board of Punishments). People's University Qing History Institute and First Historical Archives, comp. and trans. Beijing: Qunzhong chubanshe, 1985. These translations of 72 documents from 1638 and 1639 called attention to a previously unknown collection of 231 items that originated in the early ministries (Civil Appointments, Revenue, Rites, War, and Punishments), established on the Chinese model by Hong Taiji in 1631 . Covering 434 individual cases, these materials are useful for research on the pre-conquest legal system. 
Qingdai Heilongjiang lishi dang'an xuanbian (Selected compilation of historical archives on Heilongjiang in the Qing period). Heilongjiang Academy of Social Sciences Institute of History, comp. Harbin: Heilongjiang renmin chubanshe, 1986.32 of the 442 documents included in this volume, all dating between 1875 and 1881, are translated from Manchu originals. Subjects include population, border defense, gold mining, trade, and taxation.

Zheng Chenggong Manwen dang'an shiliao xuanyi Selected translations from Manchu documents on Zheng Chenggong). Volume 1. Fuzhou: Fujian renmin chubanshe, 1987. Translations from Grand Secretariat documents in the First Historical Archives concerning Zheng Chenggong (Koxinga) and the struggle for control over the southeast coast. Unlike the 1985 volume mentioned above, all of these materials are originally in Manchu. Two more volumes were supposed to be published, but have yet to appear.

Manwen Tu-er-hu-te dang'an (Manchu archives on the Torghuts). CASS Ethnology Institute and First Historical Archives (Manchu Section), trans. Beijing: Minzu chubanshe, 1988. Contains 145 documents from 1771-1775 relating to the famous "return of the Torghuts," the migration of the Torghut Mongols from the Volga to Xinjiang. The sources of these materials are the Manchu-language "Torghut Archive" (Tu-er-hu-te dang) and the Manchu monthly record books, both in the First Historical Archives (see below).

Chongde sannian dang (Archives of the third year of Chongde). Ji Yonghai and Liu Jingxian, ed. and trans. Shenyang: Liaoshen shushe, 1988. A translation of the Inner History Office archives for the year 1638 only. See the following item.

Xibozu dang'an shiliao (Historical documents on the Sibe). Wu Yuanfeng and Zhao Zhiqiang, eds. and trans. 2 volumes. Shenyang: Liaoning minzu chubanshe, 1989. This is a Chinese translation of Cing gurun-i dangse ci sonjome banjibuha Sibe-i suduri mutun (see above under Published materials: Facsimiles and Transcriptions).

Qingchu neiguoshiyuan Manwen dang'an yibian (Translated compilation of Manchu archives of the early Qing inner historical office). 3 volumes. First Historical Archives, trans. and comp. Beijing: Guangming ribao chubanshe, 1989. These valuable materials, some dating as early as 1627 , were used in the compilation of the Veritable Records of Qing Taizong (Hong Taiji) and Shizu (the Shunzhi emperor). Discovered in the First Historical Archives in the early 1980s, they were identified as originating in the Inner Historical Office (Ch. neiguoshiyuan, Ma. gurun-i suduri yamun), founded in 1636, hence their name (the documents themselves are identified only by year and month). The first volume spans the years 1633 to 1643 (no documents have been preserved from 1632 or 1641) and is very similar in content to the chronicles in the Jiu Manzhoudang and Manwen laodang. The second and third volumes 
cover the period 1644-1662, representing 52 of the original $74 \mathrm{ce}$. The translation is by staff of the Manchu Section of the First Historical Archives. Though far from complete, this is a very informative supplemental source for the history of the dynasty's first years in China.

Dalian tushuguan cang Qingdai neige daku sandie Manwen dang'an xuanbian (Selections from the dispersed Manchu archives from the Qing secretariat collection kept in the Dalian Municipal Library). 4 volumes. Tianjin: Tianjin guji chubanshe, 1989-1992. Liaoning CASS Institute of History et al., comp. Contains translations of 730 Manchu and Manchu-Chinese documents pertaining to the administration of the imperial estates (vols. 1 and 2) and the Mukden palace (vols. 3 and 4) from the Shunzhi through the Daoguang eras. These materials were originally part of the Grand Secretariat archives that were purchased by Luo Zhenyu and brought by him from Beijing to Dalian. Vols. 1 and 3 consist mostly of items from the Kangxi reign.

Fuyuan dajiangjun Yun-ti zougao (Draft translations of the memorials of Inti). Wu Fengpei, ed. Beijing: Quanguo tushuguan wenxian suowei fuzhi zhongxin chuban, 1991. This is a reworking of a previous (and rare) translation of 274 memorials of Inti, fourteenth son of the Kangxi emperor and chief rival of Injen, later the Yongzheng emperor. These documents, all in Manchu, date from 1718-1722 and are presently housed in the Beijing University Library. In the 1930s they were all translated into Chinese, but the job was poorly done. For this reissue the editor attempted to remedy the most glaring deficiencies, but as he neither understood Manchu nor had access to the original documents, the translations here must be used with caution. A partial translation of 27 of these documents appeared in Qingshi ziliao, vol. 3 (Beijing: Zhonghua shuju, 1982), 159-196.

Jilin gongpin (Tribute items frm Jilin). Jilin Provincial Archives et al., comp. Tianjin: Tianjin guji chubanshe, 1992. Contains 368 documents, all dating from after 1820, concerning tribute sent from Jilin to the capital. Forty-four of these are translations from Manchu.

Shengjing neiwufu liangzhuang dang'an huibian (Collected archives from the grain estates of the Shengjing Imperial Household Department). Tong Yonggong and Shen Wei, eds. and trans. 2 volumes. Shenyang: Liaoshen shushe, 1993. Contains over 700 documents pertaining to imperial estates in Shengjing (Mukden) housed in the Liaoning Provincial Archives. The majority of those from before the mid-eighteenth century are translations from Manchu communications to the Mukden branch of the Imperial Household Department.

Zaoqi Zhong-E dongduan bianjie yanjiu (A study of the early eastern SinoRussian border). Liu Yuantu, ed. Beijing: Zhongguo shehui kexue chubanshe, 1993). Contains translations of 22 Manchu documents pertaining to the delineation of the Sino-Russian border. 
Qingdai xiqian Xinjiang Cha-ha-er Menggu Manwen dang'an yibian (Translated collection of Manchu documents on the westward relocation to Xinjiang of the Caqar Mongols). First Historical Archives and CASS Institute for Research on the Chinese Frontier et al., comp. and trans. Beijing: Quanguo tushuguan wenxian suowei fuzhi zhongxin, 1994. With the pacification of the Dzungar menace in 1760, the Qianlong emperor took steps to safeguard the far western frontier of the empire, including the dispatch of Eight Banner auxiliary forces to permanent garrisons near Ili. Translated here are 333 documents, plus 129 attachments, relating to the relocation of 2000 Caqar Mongol households to Xinjiang. These are taken primarily from the Grand Council Manchu-language reference collection (see lufu zouzhe below). A further 594 relevant documents not translated into Chinese (mostly from the nineteenth century) are listed in the appendix.

Yuan yilai Xizang difang yu zhongyang zhengfu guanxi dang'an shiliao huibian (Collected documents on relations between the Tibetan region and the central government since the Yuan). 7 volumes. Beijing: Zhongguo zangxue chubanshe, 1994. Volumes 2 through 5 of this important collection of materials concerning the relations between Tibet and Beijing-based regimes contain hundreds of documents from the Qing period, many of them translated from Manchu originals.

Shengjing Manwen dang'anzhong de lüling ji shaoshu minzu falü (Codes and minority-peoples statutes from the Manchu archives in Mukden). Zhang Ruizhi, Xu Lizhi, eds. Volume 2 of the third series of Liu Hainian and Yang Yifan, eds., Zhongguo zhenxi falü dianzhi jicheng (Beijing: Kexue chubanshe, 1994). The first section of this collection, "Shengjing dang'an zhong de lüling," has translations of legal precedents from between 1607 and 1643, all taken from the Manwen laodang.

Qingdai Sanxing fudutong yamen Man-Han dang'an xuanbian (Selected compilation of Manchu and Chinese documents from the Qing garrison at Sanxing). Liaoning Provincial Archives, comp. and trans. Shenyang: Liaoning guji chubanshe, 1995. Continues the publication of documents from the Sanxing garrison (see above). The documents-105 from the Qianlong and Jiaqing reigns (mostly in Manchu), together with 332 documents from Daoguang and later (mostly in Chinese) - are grouped under five headings: imperial estates, immigration and colonization, defense, administrative changes, and "Russian incursions."

Kangxi chao Manwen zhupi zouzhe quanyi (Complete translation of the Manchu palace memorials of the Kangxi reign). First Historical Archives, comp. Beijing: Shehui kexue chubanshe, 1996. Translations of over 4,900 Manchu-language palace memorials from the Kangxi era. Discussed in the section on palace memorials below. 
Yongzheng chao Manwen zhupi zouzhe quanyi (Complete translation of the Manchu palace memorials of the Yongzheng reign). 2 volumes. First Historical Archives, comp. Beijing: Huangshan shushe, 1998. Translations of over 5,400 Manchu-language palace memorials from the Yongzheng era. Discussed in the section on palace memorials below.

\section{Unpublished Materials}

Manchu Materials in Taiwan. With some 387,000 documents, the National Palace Museum in Taipei holds one of the most important collections of Qing archives in the world. The most significant concentration of Manchu-language documents is the Manchu palace memorials, described later in this article, but there are also other holdings of Manchu materials, mainly from the Grand Council archives. These include monthly memorial packets, yifu dang, shangyu dang, and scattered items in some topic-specific Grand Council archives. ${ }^{16}$ In addition, the Manchu-language Diaries of Activity and Repose (Ch. qijuzhu, Ma. ilire tere be ejere dangse) form an extremely valuable set of materials. The position of court diarist, charged with recording everything the emperor did and said, was created in 1671. From that year on, diaries exist in draft and final versions, both in Chinese and in Manchu, for most of the Qing. These materials were a basic source for the compilation of the Veritable Records, than which they are often fuller and more detailed. One suspects that the content of the Manchu qijuzhu is similar to that of its Chinese-language counterpart (of which the portions for the Kangxi and Yongzheng reigns held in the FHA have been published), ${ }^{17}$ but a detailed comparison has yet to be made. Not including those from the nineteenth century, the NPM possesses fairly complete runs of the Manchu volumes (twelve per year at first, twenty-four per year after 1722) for 1671-1703, 1711-1713, 1730-1748, 1751-1753, 1755-1757, 1765-1770, 1774-1778, 1781, 1783-1784, 1789-1792, plus thirteen volumes recording the affairs of the Qianlong emperor in retirement (from $1795-1799) .{ }^{18}$

\footnotetext{
16 These materials are described in Chuang Chi-fa, Gugong dang'an shuyao (Taipei: National Palace Museum, 1983), 138, 231, 253, 261, 274-279. See also the description of Grand Council archives below. 17 Kangxi chao qijuzhu ce, First Historical Archives, comp. (3 vols.; Beijing: Zhonghua shuju, 1984) and Yongzheng chao qijuzhu ce, First Historical Archives, comp. (5 vols.; Beijing: Zhonghua shuju, 1993). In the introduction to the Kangxi set, it is stated that the contents of the Manchu and Chinese versions are "absolutely identical" (wanquan yizhi), but in the preface to the Yongzheng set, only that they are "similar" (xiangtong).

18 See Chuang, Gugong dang 'an shuyao, 299-300, for details on volumes in Chinese and on all holdings of qijuzhu from the Jiaqing and later reigns.
} 
Apart from the NPM, there are also Manchu documents at the Institute of History and Philology at Academia Sinica. These are part of the Institute's Ming-Qing Archives, totaling approximately 310,000 items, which formerly belonged to the Grand Secretariat archives. Routine memorials are the most numerous single type of document, and almost all of these retain a Manchu half; in addition, there are roughly 7,000-10,000 routine memorials in Manchu only. ${ }^{19}$ Other Manchu-language documents include edicts, huangce, and zouxiao dang. Most of the Manchu materials here have yet to be carefully catalogued. It should not be ruled out that many rare and important items may surface when this collection has been more thoroughly organized.

Manchu Materials in Shenyang. The Liaoning Provincial Archives (LPA), sometimes also known as the Third Historical Archives (the Second Historical Archives, housing records from the Republican period, is in Nanjing), is the largest provincial-level archives in China, with over 1,500,000 holdings. The LPA has about 200,000 items from the Qing period, of which an estimated $10 \%$ or so consists of materials in Manchu. ${ }^{20}$ The majority of these materials originated in the Mukden (Shengjing) Imperial Household Department. Among them are population registers (Ch. hukouce), some of which are in Manchu, and the Shunzhi nianjian dang (see above under "Published Materials: Facsimiles and Transcriptions"); archives similar to the latter exist for later reigns through Xianfeng. Until the middle of the Qianlong period, they are all in Manchu only; those for the later eighteenth and early nineteenth century are in both languages, and those for the Daoguang and Xianfeng reigns are in Chinese only.

Also in the LPA holdings are the so-called "lateral files" (Ch. hei-tu dang, Ma. hetu dangse or heturi dangse), copybooks of interdepartmental correspondence between the Mukden Imperial Household Department and other government offices in Mukden and Beijing. These materials, bound in 1,169 ce, date from the period between 1661 and 1861; all but the last forty years (212 ce) are almost entirely in Manchu. Many copybooks are quite substantial, running to over 100 pages, though there are gaps in certain years. Among the subjects covered by this correspondence are the management of imperial estates, household registration, finance, granaries, legal disputes, and products sent to the court in Beijing. ${ }^{21}$ The breakdown by reign and type of document (jinglai is correspondence from the Beijing Imperial Household Depart-

\footnotetext{
19 Chang We-jen, personal communication, March 2000. On routine memorials, see below.

20 Zhao Yunpeng, personal communication, September 1990.

21 These materials are discussed in more detail in Bartlett, "Books of Revelations." Translations of 79 documents from 1665-1671 appeared in Qingshi ziliao, vol. 5 (Beijing: Zhonghua shuju, 1984).
} 
ment; jingxing is correspondence to the Beijing Imperial Household Department; bulai is correspondence from other local bureaux in Mukden; buxing is correspondence to other Mukden bureaux) is shown in Table 1.

Another substantial archive left by the Mukden Imperial Household Department is the Drafts Archive (gaodang), consisting of original documents (as opposed to copybooks) from 1750 to the early Republican period. There is a fine catalogue ( 9 volumes, approx. $350 \mathrm{pp}$. per volume), divided by reign and by the nature of the communication, with a content summary of each item. The majority, though not all, of these documents are in Manchu. There are also Manchu materials in some of the LPA's other main Qing collections: the Mukden Board of Rites archives (Shengjing libu dang), the Mukden Garrison General archives (Shengjing jiangjun yamen dang), the Sanxing Garrison Archives (Sanxing fudutong yamen dang; see above), and the Shuangchengpu archives (Shuangchengpu dang), the latter a collection of 2,300 ce of materials (from 1850-1923) on the Eight Banner agricultural colony at Shuangchengpu in Heilongjiang. ${ }^{22}$

Manchu Materials in Beijing. By far the most important collection of Manchu archives to be found anywhere is that in the First Historical Archives in Beijing. While it is impossible to speak of a precise number of documents, the usual figure cited is that one-fifth of the FHA's total holdings, or about 2,000,000 items, consists of materials wholly or partly in Manchu. ${ }^{23}$ The majority of these materials date from before 1800 , but there are tens of thousands of documents in Manchu from the nineteenth and even the early twentieth century. Manchu materials in the FHA are mostly found in one of six central record groups (quanzong): Grand Secretariat, Grand Council, Eight Banner Command, Imperial Palace, Imperial Household Department, and Imperial

\footnotetext{
22 Details on these and the rest of the holdings in the LPA may be found in Liaoning sheng dang'anguan zhinan (Beijing: Zhongguo dang'anguan chubanshe, 1994).

23 These were the figures quoted to me in 1990 by the staff of the Manchu Section of the FHA (this includes Manchu-language tiben). They appeared in print in a 1994 article by the chief of the Manchu Section. See Wu Yuanfeng, "Qingdai neige Manwen dang'an shulue," Manxue yanjiu 2 (1994), 274. This number must still be regarded as a guess. In a 1994 essay, archivist Guan Xiaolian wrote that there are 3,000,000 Manchu-language items in the FHA, approximately one-half of which are not "duplicated" (chongfu) by Chinese-language documents ("Qing Kangxi chao Manwen zhupi zouzhe chuyi," Lishi dang'an 1994.1, 84). In the "Afterword" to the 1996 Kangxi chao Manwen zhupi zouzhe quanyi, archivist Wang Xi claimed that there are over 1,600,000 Manchu archives in the FHA, accounting for "one-sixth of the archives' total holdings" (p. 1725), while the foreword to the 1998 Yongzheng chao Manwen zhupi zouzhe quanyi returns again to the earlier figure of 2,000,000 (p. 2), noting in addition that the FHA holdings represent $80 \%$ of all extant Manchu archives. Wang's estimate corresponds to the figure cited in Wilkinson, Chinese History: A Manual (rev. ed.), 926.
} 
Table 1: The Mukden "Lateral Files" Archives: Distribution by reign and document type.

\begin{tabular}{|l|l|l|l|l|l|l|}
\hline Reign & 京來 & 京行 & 部來 & 部行 & 存查 & $\begin{array}{l}\text { Total ce by } \\
\text { reign }\end{array}$ \\
\hline Kangxi & 46 & 58 & 45 & 63 & 3 & 215 \\
\hline Yongzheng & 11 & 13 & 40 & 27 & 0 & 91 \\
\hline Qianlong & 49 & 51 & 169 & 165 & 5 & 439 \\
\hline Jiaqing & 20 & 25 & 92 & 65 & 10 & 212 \\
\hline Daoguang & 19 & 15 & 57 & 42 & 19 & 152 \\
\hline Xianfeng & 7 & 6 & 26 & 16 & 5 & 60 \\
\hline Total ce by type & 152 & 168 & 429 & 378 & 42 & 1169 \\
\hline
\end{tabular}

Source: Hei-tu dang catalogue, LPA.

Clan Court. The first four of these are each discussed in turn below. Discussion of the last two is saved for a future occasion. ${ }^{24}$

Grand Secretariat Archives. The earliest Manchu-language documents in the FHA belong to this record group. The Grand Secretariat (Ch. neige, Ma. dorgi yamun), an institution inherited from the Ming, occupied a position of steadily decreasing importance under the Qing dynasty, but it handled most regular communications between officials and the throne throughout the period, so its archives are the most abundant. Several different types of valuable documents are preserved in this group, including routine memorials, shishu, piaoqian dang, silunbu, and huangce. Other Manchu-language holdings include the Mishuyuan dang, miben dang, Qingzhe dang, shangyu dang, and Baqi shixipu dang, as well as the mostly pre-conquest Manwen laodang and Neiguoshiyuan dang. ${ }^{25}$

24 Of Imperial Household Department (Ch. neiwufu, Ma. dorgi baita be uheri kadalara yamun) archives, I have examined only a few items from the zouxiao dang. Evelyn Rawski makes use of some items from this group in her book, The Last Emperors. Some sense of the different types of documents contained in the Imperial Household Department archives can be gained by perusing the catalogues created to accompany microfilm made for the Utah Genealogical Society by the FHA in 1984. In addition to extensive holdings on personnel matters in the Imperial Household, the Eight Banners, and the Imperial Clan Court, there also appear to be substantial collections of household registers, genealogies, and "sacrifice registers" (Ch. jice), many of which are in Manchu.

${ }_{25}$ A comprehensive list of the Manchu materials in the Grand Secretariat archives may be found in Wu, "Qingdai neige Manwen dang'an shulue." 
Routine memorials, or tiben (Ma. ben), are the most numerous of any type of document in the FHA, numbering upwards of one million. They are reports on every sort of civil and criminal matter from all over the empire, a treasure house of information for the historian. When submitting a routine memorial, Qing officials were required to quote in full all preceding communication on the same item of business. As a result, tiben are often of extraordinary length, frequently $3-5 \mathrm{~cm}$ in thickness, and often highly redundant. Luckily for historians, memorials were summarized before presentation to the emperor, and a summary, called a tiehuang (Ma. tukiyehe sosohon), is usually found glued or copied at the end of every tiben. However, the tiehuang does not include the final decision on a given matter, which is usually written in neat script in red ink on the front of the memorial. In the not uncommon case that the cover, tiehuang, or first few pages of tiben are damaged or lacking, it is worth recalling that tiben were in principle bilingual (Ch. hebi) and thus possess, in effect, two fronts, one in Chinese (read from right to left) and one in Manchu (read from left to right). Reference to the extant Manchu half of a routine memorial can supply information that was written in the missing Chinese half, as well as help to clarify the meaning of obscure Chinese passages.

Though tiben are the most numerous of any document type, only three thousand remain from the first three reign periods, catalogued in two groups. One group, Qiansanchao tiben, (cat. no. 13/2-11-1, 2-11-2) contains over one thousand items from the Shunzhi, Kangxi, and Yongzheng reigns, classified according to subject matter; another 1,782 items, classified by reign and board office, are catalogued separately as Neige tiben (cat. no. 580/2-206). This dearth of routine memorials is a problem for research in the early Qing. Luckily, other types of bilingual archives, like the shishu, offer some help. The shish $u$ consist of copies of tiben written on inferior quality paper of varying dimensions, bound together in monthly volumes. On the first page for a given day is a note on the date and the number of entries for that day; however, this note does not always appear and, as explained below, is often unreliable. Beginning in 1653, there are shish $u$ for each office (Ch. ke, Ma. k'o or kunggeri) of the Six Boards (Ch. liubu, Ma. ninggun jurgan) (in Manchu, the shishu are called simply the "files [dangse] of such-and-such year for suchand-such office"). Apart from date and office, there is no further subdivision of materials in the shishu. This can be either an advantage or a disadvantage, depending on one's research goals. It appears that in the beginning tiben were copied in their entirety for inclusion in the shishu, which makes them a very noteworthy substitute for nonexistent tiben; by the Qianlong reign, however, entries grow significantly shorter, often amounting to just a brief summary of the original. 
It is very fortunate that the shishu from the first three Qing reigns are quite numerous. Yet scholars wishing to consult the shishu still face a few difficulties. One is that, like so many other types of materials, many shishu are missing or are in very poor condition and may not be available for consultation. A second is that their use is extremely time-consuming. While entries are systematic, there are no summaries, and even though the script is usually quite legible, to find items relevant to a specific research topic (unless it is tightly limited chronologically) requires great patience. Beyond this, careful inspection of the Chinese and Manchu sections of the shishu reveals a third problem. At the end of certain Manchu memorials is written the memorandum, ere ben de Nikan bithe akū ("No Chinese for this memorial"). Thus a certain portion of entries exists solely in Manchu, and one is bound to miss something if one relies only on the Chinese. The percentage of Manchu-only entries varies with each volume. Moreover, not all Manchu-only entries are so annotated, necessitating an entry-by-entry comparison for content. Such a comparison on six separate volumes of the shishu (for the offices of the Boards of War and Punishments) for 1653 revealed an average $17 \%$ more memorials in Manchu than in Chinese (most of these Manchu-only entries deal with military and frontier affairs). ${ }^{26}$ Further use of these materials is needed before we will know more about their value and peculiar features. ${ }^{27}$

Compilation of the shishu was one part of the complex process by which memorials from local and capital officials were handled by the central government and became part of the official record. ${ }^{28}$ Another step in the process was the drafting of rescripts, the means by which the staff of the Grand Secretariat recommended responses to the emperor. These recommendations, known as piaoqian (Ma. dahabure afahari),were written on separate slips of paper that were forwarded together with the memorial to the throne. Piaoqian are presently found in two separate places. One, the Man[wen] piaoqian dang

\footnotetext{
26 For more details, and sample statistics for one volume of the bingke shishu, see my article, "Chügoku dai'ichi rekishi tōankan shozō naikaku kyūchū Manbun tōan gaijutsu," trans. Yanagisawa Akira, Tōhōgaku 85 (1993), 151-152.

27 A step in this direction is Kusunoki Yoshimichi, "Rika shisho chū no Rihan'in daihon," Manzokushi kenkyū tsū shin 5 (1995), 33-42, and Amari Hiroki, "Heika shisho chū no heibu shōsho Gadafun nado no daihon ni tsuite," Manzokushi kenkyū tsū shin 8 (1999), 10-25. Kusunoki notes that the shishu can substitute for missing Lifanyuan documents; Amari has found that in some cases where the original memorial was in Chinese, the Manchu entry represents only a summary. Note that there are a substantial number of shishu as well in the National Palace Museum archives. See Chuang, Gugong dang'an shuyao, 314-316. 28 Regular memorials from local officials arrived at the Transmission Office (Ch. tongzheng si) and so were known officially as tongben; memorials from officials in the capital were called buben ("board memorials"). After translation, the memorials were sent first to the Grand Secretariat, which prepared draft responses for the emperor's convenience (these also had to be translated). They were then presented to the emperor for a decision.
} 
(cat. no. 580/2-206) contains 16,250 such slips, beginning in the Shunzhi reign. Each slip is the size of one fold of a memorial; the recommendation is written in Manchu on the left and in Chinese on the right. On the back of some (not all) piaoqian slips are written the names of the recommending officials. Very occasionally a piaoqian is only in Manchu, and sometimes one comes across changes made by the emperor to the original recommendation (these are usually in Chinese). The greatest drawback to their use is that these slips, which are now separated from the memorials they accompanied, have only the month and day noted on them, and not the year. At present there is no easy means of cross-referencing them to other materials. The other collection of piaoqian has been bound into 102 ce dating from 1645-1652 (cat. no. 200/2107). These are more detailed than the slips in the preceding catalogue, being comparable in detail to the shishu (like them, there is at least one volume per month) and would serve as an excellent source for research on the first years of the Qing.

Once rescripted, memorials were recorded in another type of record book in the Grand Secretariat before being sent on. These books, called silunbu (Ma. ba de pilehe hese [be ejehe] dangse, "records of rescripted edicts"), exist in separate Chinese (cat. no. 39/2-37) and Manchu (cat. no. 51/2-49) versions, bound in yellow paper, one per month (later more frequently), and, like the shishu, are divided according to board office. ${ }^{29}$ Generally they are in good condition. Entries are very short, usually only one or two lines listing the memorialist, the decision, and the type of matter. For the early Qing, Manchu volumes decidedly outnumber those in Chinese (for the Shunzhi reign, 5 volumes remain in each language; for Kangxi, 82 Manchu and 69 Chinese; for Yongzheng, 131 Manchu and 25 Chinese). For volumes of the same month, contents appear to be identical; there is not the same phenomenon of Manchuonly entries as in the shishu. While useful for making summaries of types of cases handled, the silunbu are probably mostly limited to serving as finding aids, and even at that are probably not as easy to use as the tiben catalogues prepared by the FHA.

Another important type of Manchu-language record preserved in the Grand Secretariat archives are finance reports, called "yellow registers" (Ch. huangce, Ma. suwayan-i dangse), for their yellow silk covers, of which at least 2,000 remain in Manchu from 1645-1903 (cat. no. 184/2-106-1, 2-106-2)..$^{30}$ Origi-

\footnotetext{
29 The Chinese volumes are divided differently, with entries from different boards all in one volume, divided up daily. Beatrice S. Bartlett, personal communication, March 2000.

30 The catalogues I examined listed a total of 1,945 ce. However, Wu claims a figure of 3,500 Manchu huangce (Wu, "Qingdai neige Manwen dang'an shulue," 278). I am at present unable to reconcile this difference.
} 
nating from the Six Boards, the Imperial Clan Court (Ch. zongrenfu, Ma. uksun be kadalara yamun), Court of Colonial Dependencies (Ch. lifanyuan, Ma. tulergi golo be dasara jurgan), the Guanglu si and Taichang si, these reports contain remarkably detailed monthly accounts of income, expenses, salary payments, taxes, debt service, and a range of related fiscal matters covering all branches of the central and provincial bureaucracy. Further research may show how these materials complement the Chinese-language huangce.

In addition to those just described, there are a number of smaller, discrete concentrations of Manchu-language materials in the Grand Secretariat archives. The Mishuyuan dang and miben dang (cat. no. 200/2-107), both copybooks from the Shunzhi and Kangxi reigns, were originally composed in the Inner Chancellery (Ch. neimishuyuan, Ma. narhün bithei yamun), established by Hong Taiji at the same time as the Inner Historical Office. The Mishuyuan dang, in $78 \mathrm{ce}$, covers the period 1644 through 1688 (roughly one volume per month) and consists mostly of imperial proclamations, sacrificial texts, and bestowals of titles. The $153 \mathrm{ce}$ of the miben dang, covering the years 1653 to 1680 , consist mainly of translated tiben from officials in south China (the Chinese originals are now lost). There is much valuable material here on the early years of the Qing conquest, particularly the suppression of rebellion and the court's relations with the Zheng family, some of which has been translated and published (see above). There is also a substantial amount on Jesuit relations, including the case of Adam Schall von Bell. The Menggutang dang (cat. no. 200/2-107) and E-luo-si dang also date from the early years of the dynasty, beginning in the $1650 \mathrm{~s}$, but extend later, to the 1780s. The "Mongolian chancellery" (Ch. Menggutang, Ma. Monggo bithei ba) was an office within the Grand Secretariat responsible for handling communications in different languages (Mongolian, Tibetan, Uighur, Russian) with the various nonHan peoples with whom the empire had regular contact. ${ }^{31}$ Cataloguing of the Menggutang archives is still in the beginning stages, ${ }^{32}$ making it impossible to say for certain how many items it contains, but the number is not fewer than 133 jian, some of which are hundreds of pages long. The majority of documents dates from the Kangxi era and includes communications with the Dalai Lama and other Buddhist prelates, Mongol nobles, Galdan, Ts'ewang

\footnotetext{
31 This summary relies on Shibuya Kōichi, "Chūgoku dai'ichi rekishi tōankan shozō 'Mōkōdōtō' oyobi 'Manbun sōshoku' ni tsuite," Manzokushi kenkyū tsūshin 8 (1999), 21-31; see also Wu, "Qingdai neige Manwen dang'an shulue," 280. As Shibuya makes clear, the Eluosi dang consists of documents originally in the Menggutang relating to Russia that were later separated into a separate file. These were published in 1981 (see above).

32 There are two catalogues, one for the Menggutang itself, and one labeled Manwen zouchi, which, as its contents demonstrate, also holds materials from the Menggutang. The Manwen zouchi documents are bound into five volumes totaling approximately 450 pages.
} 
Rabtan, and others. There are also Manchu translations of the Liao and Yuan histories as well as the testaments of the Kangxi and Yongzheng emperors. Yet another deposit of Manchu-language materials is the Lichao baqi zadang, part of a little-known file called the Qingwen zadang, catalogued together with miscellaneous Grand Secretariat records. ${ }^{33}$ In the Lichao baqi zadang are 349 documents, including a number of Eight Banner genealogies and various materials on succession to the position of company captain (Ch. zuoling, Ma. nirui janggin), which appear to have been retained after the writing of the first edition of the Complete History of the Eight Banners (Ch. Baqi tongzhi chuji, Ma. jakūn güsa sucungga tungjy-i bithe), which was the occasion for their submission.

Last among the Grand Secretariat archives described here are the qingzhe dang, the shangyu dang (cat. 200/2-107), and the Baqi shixipu dang (cat. no. 38/2-36). The first covers the entire Qianlong reign (1736-1795) and the beginning of the Jiaqing reign (1796-1804). These files consist of palace memorials (Ch. zouzhe, Ma. jedz, bukdari) originally sent by capital officials to the Grand Council, which then furnished copies to the Grand Secretariat. Compiled seasonally until 1795 and monthly thereafter, of a purported 348 volumes, 102 are extant. ${ }^{34}$ Content is apparently similar to the lufu zouzhe and the yuezhe dang (see below). The second set of documents, the shangyu dang, is an incomplete set of registers of imperial edicts from between 1723 and 1803, reference copies made for retention in the Grand Secretariat. ${ }^{35}$ Third, the Baqi shixipu dang ("Eight Banner genealogy files"), contains several hundred court-commissioned genealogies and charts of captaincy succession from the Yongzheng through Guangxu reigns, with the preponderance from the nineteenth century. ${ }^{36}$ Similar materials are also found in the Eight Banner Command archives, described below, and in the Imperial Household Department archives.

Grand Council Archives. The Grand Council (Ch. junjichu, Ma. coohai nashün-i ba), considered one of the most important institutional innovations under the Qing, arose in the 1720 s to provide a more efficient and, at least at first, more confidential means of conducting the business of the empire, espe-

\footnotetext{
33 I rely here on Sugiyama Kiyohiko, "Chūgoku dai'ichi rekishi tōankanzō 'Rekichō hakki zatsutō' kanshō," Manzokushi kenkyū tsūshin 8 (1999), 47-59.

34 The catalogue notes $111 \mathrm{ce}$. I have used the figure in Wu, "Qingdai neige Manwen dang'an shulue," 279 , upon which this summary relies.

${ }_{35}$ Missing are QL3-10, 14, 17-20, 26-27, 29, 32, 36, 39, 41, 50-60, JQ 1 and 3. See Qu Liusheng, "Qingdai junjichu Manwen dang'an zongshu," Lishi dang'an 1989.1, 128. The Chinese shangyu dang for the Qianlong reign have been published in 18 vols. by the FHA as Qianlong chao shangyu dang (Beijing: Dang'an chubanshe, 1991).

36 The catalogue says 445 items; Wu says 763 .
} 
cially its military affairs. ${ }^{37}$ By the 1730 s it had become the premier decisionmaking body in the entire government. The archives of the Grand Council, which are extensive and extremely varied, are thus of tremendous historical value. In Manchu, the most important collections are the cumulative yuezhe bao ("monthly memorial packets") and yuezhe dang ("monthly memorial record books"), but there is also a large number of topic-specific record books as well, many of which are of research interest.

The yuezhe bao and yuezhe dang (cat. no. 206/3-49) represent the systematically recorded copies of virtually all the correspondence that passed through the Grand Council between 1730 and 1911. Compilation occurred at first on a seasonal basis, but quickly moved to a monthly (later semi-monthly) basis, with internal organization proceeding in a strict chronological, day-by-day order. Until 1761, contents were divided into two categories, military (Ch. junwu) and routine (Ch. xunchang), the former accounting for the lion's share, perhaps as much as $80 \%$. This division was abandoned in the 1760 s after the final quelling of the Dzungar revolt. ${ }^{38}$ The Manchu name of these archives, wesimbuhe bukdari-i dangse ("record of submitted palace memorials"), is a bit misleading since not only memorials, but all accompanying materials, as well as rescripts (and dates of rescripts), were also copied into the files. In this regard, as Bartlett has pointed out, the yuezhe bao and yuezhe dang are an even more valuable resource than the palace memorials, which are now separated from their supplementary documents. The Chinese version of the yuezhe bao is commonly known as the lufu zouzhe ("Grand Council reference collection"), though the preponderance of the Manchu yuezhe bao consists, of course, of lufu zouzhe, too. Thus the yuezhe bao are sometimes referred to as the Manchu lufu zouzhe.

The Chinese lufu zouzhe archive differs from the Manchu yuezhe bao in two essential ways. First, the content of these two archives is entirely separate. Unlike tiben, palace memorials were not translated during transmission to the emperor. Each item is therefore unique: there is no duplication, that is, no Manchu version and Chinese version of the same report, save for the occasional bilingual memorial. Matters relating to the conduct of military campaigns, frontier policy in the north and west, and the Eight Banners were almost always reported on only in Manchu, although other matters, especially if the memorializing official happened to be a bannerman, might also be in Manchu. By definition, then, these memorials are not found among the Chi-

\footnotetext{
37 The definitive work on the origins of the Grand Council is Bartlett, Monarchs and Ministers, where additional detailed information on the various types of Qing documents may be found.

$38 \mathrm{Qu}$, "Qingdai junjichu Manwen dang'an zongshu," 125; Wu Yuanfeng, "Junjichu Manwen yuezhe bao ji qi zhengli bianmu," Qingshi yanjiu 1991.1, 61.
} 
nese lufu zouzhe..$^{39}$ In their present organization as well, the lufu zouzhe are fundamentally different from the Manchu yuezhe bao. In the 1950s and 1960s, the Chinese lufu zouzhe were removed from their original monthly packets and reorganized according to the so-called "eighteen big topics" (shiba da lei) so well known to anyone who has used the FHA. With the exception of materials between 1730 and 1755, which were also reorganized by topic, however, the Manchu yuezhe bao were left alone; they have now been catalogued in a way that respects the original chronological nature of the archive. Moreover, the materials in the Manchu yuezhe dang - in effect, a supplementary copy of the entire yuezhe bao made in the form of a record book - are entirely undisturbed (the Chinese-language yuezhe dang is much less complete).

Hence the Manchu yuezhe bao and yuezhe dang are both vast. Estimates are that there are 180,000-200,000 items in the former (almost one-fourth of all lufu zouzhe), and some 2,400 ce in the latter. ${ }^{40}$ Both have been microfilmed in their entirety. Cataloguing of the former, as mentioned, began in the $1950 \mathrm{~s}$, but the catalogue of the yuezhe dang is purely a chronological list. Happily, an extremely useful finding aid to the yuezhe bao (and, by extension, the yuezhe dang) has recently been published. This is the twelve-volume Catalogue of Manchu Archives on the Qing Frontier, which references thousands of individual entries in the yuezhebao pertaining to a wide range of subjects in connection with the frontier regions (interpreted to include not just the north and west, but also the southwest and the coastal provinces).$^{41}$ Entries are divided by region and are then arranged chronologically. Each entry shows the date of the item, a brief extract giving the name and position of the memorialist and the subject of the communication (plus any supplementary documents), followed by two code numbers: the first corresponds to the document itself and the second to the location of the microfilmed item by reel and frame. The appearance of this fine catalogue should do much to spur interest in and use of the Manchu archives.

\footnotetext{
39 For this reason, apart from the relatively small number of Manchu-Chinese hebi memorials, there can be no "comparison of Manchu-language palace memorials with their Chinese counterparts," as has been suggested (Crossley and Rawski, “A Profile,” 70).

40 Qu says 180,000 ("Qingdai junjichu Manwen dang'an zongshu," 126); the foreword to Yongzheng chao Manwen zhupi zouzhe quanyi says “almost 200,000” (2). Citing statistics compiled in 1930, Qu notes that a total 800,000 lufu zouzhe are extant.

41 Qingdai bianjiang Manwen dang'an mulu, First Historical Archives, People's University Qing History Institute, and the Chinese Academy of Social Sciences Chinese Frontier Research Center, comp. (Guilin: Guangxi shifan daxue chubanshe, 1999). Vol. 1 contains materials for Mukden; Vol. 2 for Jilin and Heilongjiang; Vol. 3 for Inner Mongolia; Vols. 4-5 for Uriyasutai; Vols. 6-11 for Xinjiang; Vol. 12 for Tibet, Zhili, Shandong, Jiangsu, Zhejiang, Guangdong, Guangxi, Yunnan, Fujian, and Taiwan. Another important new catalogue is Zhongguo diyi lishi dang'anguan suocun Xizang he Zangshi dang'an mulu: Man, Zang wen bufen (Beijing: Zhongguo Zangxue chubanshe, 1999). Dedicated to sources pertinent to Tibet and Tibetan affairs during the Qing, this catalogue covers not only the Manchu lufu zouzhe, but many other types of documents as well. There is an index.
} 
There are four other substantial cumulative archives in the Manchu Grand Council collection, all of which are listed in the junjichu Manwen dangbu mulu (cat. no. 193/3-47-2 and 3-47-3). One is the shangyu dang ("record of imperial edicts"), which, at over $600 \mathrm{ce}$, contains an incomplete run from 1732 through 1910. The second is the yifu dang ("record of deliberations"), in $730 \mathrm{ce}$, which contains copies of deliberations on items of Grand Council business between 1730 and 1910 . These were compiled on a quarterly basis. The third is the jixin dang ("record book of court letters"), in 200-odd volumes. These are copies of edicts sent by Grand Councillors to provincial officials between 1761 and 1881 (about one-fifth of these date from the Qianlong reign). The fourth and last is the riji dang ("chronological record," Ma. ibebuhe ben be ejehe dangse, "record of presented routine memorials"), in $406 \mathrm{ce}$, which runs from 1755 to 1908 (there are two earlier ce in the Imperial Palace record group; see under Manwen zadang below). This is a handlist (in Manchu only, with occasional Chinese characters) similar to the suishou dengji recording the dispensation of items of business on a given day at court. Entries are brief ("Edict to so-and-so regarding such-and-such") and proceed chronologically. It seems that only business being handled in Manchu was recorded here. Notations are made as to whether something is to be copied (i.e., into the lufu zouzhe), and where the emperor was that day (e.g., Rehe).

The above account for some $70 \%$ of Grand Council Manchu-language archives. ${ }^{42}$ In addition, there are a large number of topic-specific archives (also in the same catalogue as the immediately preceding). These are summarized in Table 2, grouped by general subject of relevance. ${ }^{43}$

Eight Banner Command Archives. The office of the Eight Banner Command (Ch. baqi dutong yamen, Ma. jakūn gūsai yamun) was established by the Yongzheng emperor in 1723 (no central administrative system for the Eight Banners existed prior to this). The documents left by this office therefore date from after the early $1700 \mathrm{~s}$, and most come from the $1800 \mathrm{~s}$. The majority of items is in Manchu, but the proportion of Chinese-language documents increases over time. Archivists have gathered these materials into 856 bundles and separated them into fourteen different categories (see Table 3 ) in one catalogue (cat. no. 544/23-2). There is no official estimate as to their number; my conservative guess is that there are not fewer than 20,000 individual documents here. Brief descriptions of the most important concentrations of documents follow below.

${ }^{42} \mathrm{Qu}$, "Qingdai junjichu Manwen dang'an zongshu," 126.

43 I have somewhat modified the categorization adopted by Qu Liusheng in his description of these materials. This grouping reflects neither their organization in the Qing or in the FHA catalogues. Another useful description of some of these materials is Wu Yuanfeng and Zhao Zhiqiang, "Manwen dang'an yu Qingdai minzushi yanjiu," in Ming-Qing dang'an yu lishi yanjiu (Beijing: Zhonghua shuju, 1988), 441449. 
Table 2: Topic-specific archives in the Grand Council Manchu-language collection

\begin{tabular}{|c|c|c|c|c|}
\hline Item & Date & No. of ce & Remarks & Subject \\
\hline \multicolumn{5}{|l|}{ Personnel } \\
\hline 1.引見檔 & $1809-1908$ & 23 & & imperial audiences \\
\hline $\begin{array}{l}\text { 2. 應放副都統各項 } \\
\text { 人員檔 }\end{array}$ & $1812-1889$ & 30 & & appointments \\
\hline 3. 新疆檔 & $\begin{array}{l}1819,1836- \\
1911\end{array}$ & 30 & $\begin{array}{l}\text { per catalogue; Qu } \\
\text { says contents } \\
\text { limited to } 1819 \text { - } \\
1861\end{array}$ & appointments \\
\hline 4. 大員子弟交片檔 & $?$ & $?$ & $\begin{array}{l}\text { not in catalogue; } \\
\text { described in Qu }\end{array}$ & appointments \\
\hline 5. 軍政卓異檔 & $1832-1897$ & $?$ & $\begin{array}{l}\text { not in catalogue; } \\
\text { described in } \mathrm{Qu}\end{array}$ & appointments \\
\hline $\begin{array}{l}\text { 6. 正蕉旗滿洲官 } \\
\text { 員册 }\end{array}$ & 1784 & 1 & Qu omits & personnel register \\
\hline \multicolumn{5}{|c|}{ Imperial tours, Rehe, Mukden } \\
\hline 7. 東京總理檔 & $1735-1765$ & 23 & Qu omits & unknown \\
\hline 8. 盛京檔 & $1741-1829$ & 16 & & Mukden palace \\
\hline 9. 木蘭檔/外圍檔 & $1741-1861$ & 109 & bilingual & imperial hunts \\
\hline 10. 五臺檔 & $1746-1811$ & 8 & & Wutai shan \\
\hline 11. 留京辦事檔 & $1746-1803$ & 84 & & $\begin{array}{l}\text { reports from capital } \\
\text { during tour }\end{array}$ \\
\hline 12. 山曺檔 & $\begin{array}{l}1748-1749, \\
1771\end{array}$ & 2 & & Southern Tours \\
\hline
\end{tabular}


Table 2: Continued

\begin{tabular}{|c|c|c|c|c|}
\hline 13. 江南檔 & $\begin{array}{l}1750-1751, \\
1762-1765\end{array}$ & 8 & & Southern Tours \\
\hline 14. 和圖利檔 & $1750-1786$ & 21 & Qu omits & Mukden \\
\hline 15. 處事檔 & $1765-1854$ & 21 & Qu omits & Mukden \\
\hline 16. 留京檔 & $1767-1784$ & 9 & & $\begin{array}{l}\text { reports from capital } \\
\text { during tour }\end{array}$ \\
\hline 17. 天津檔 & $1794-1807$ & 4 & & Southern Tours \\
\hline \multicolumn{5}{|c|}{ Frontier and military affairs } \\
\hline 18. 俄羅斯檔 & $\begin{array}{l}\text { Kangxi reign - } \\
1889\end{array}$ & 50 & & Russia \\
\hline 19. 俄羅斯來文 & $\begin{array}{l}\text { Kangxi reign - } \\
1791\end{array}$ & 17 & & Russia \\
\hline 20. 北路軍務 & 1731 & 37 & & Dzungars \\
\hline 21. 非究焊郎 & $1731-1748$ & 9 & & Dzungars \\
\hline 22. 俄羅斯行文 & $1732-1887$ & 98 & & Russia \\
\hline 23. 夷使檔 & $1734-1754$ & 8 & & $\begin{array}{l}\text { Dzungar emissaries } \\
\text { to Beijing }\end{array}$ \\
\hline 24. 減郎 & $1741-1748$ & 4 & & $\begin{array}{l}\text { Dzungar missions to } \\
\text { Tibet }\end{array}$ \\
\hline 25. 西路檔 & $1743-1747$ & 2 & & \\
\hline 26. 金川檔 & $1748-1776$ & 11 & $\begin{array}{l}\text { Qu says } 1769- \\
1776\end{array}$ & $\begin{array}{l}\text { Jinchuan wars; } \\
\text { inciudes draft of } \\
\text { Jinchuan fanglue }\end{array}$ \\
\hline 27. 西藏檔 & $1750-1751$ & 13 & & Tibet \\
\hline
\end{tabular}


Table 2: Continued

\begin{tabular}{|c|c|c|c|c|}
\hline & $1788-1791$ & & & \\
\hline 28. 俄羅斯外文 & $\begin{array}{l}1756-1788, \\
1851-1854\end{array}$ & 24 & & Russia \\
\hline 29. 年班來京藩檔 & $1763-1819$ & 10 & & $\begin{array}{l}\text { annual embassies to } \\
\text { Beijing }\end{array}$ \\
\hline 30. 土爾扈 特 檔 & 1771 & 24 & $\begin{array}{l}\text { published in } \\
\text { translation }\end{array}$ & Torghuts \\
\hline 31. 班禪事件檔 & $1779-1781$ & 10 & & $\begin{array}{l}\text { visit of Panchen } \\
\text { Lama to Chengde }\end{array}$ \\
\hline 32. 哈薩克檔 & $1783-1791$ & 4 & & Khazakhs \\
\hline 33. 回子伯克檔 & $1786-1851$ & 7 & & Muslim begs \\
\hline 34. 巴勒布檔 & 1789 & 4 & & Tibet \\
\hline 35. 廓爾克[客]檔 & $1791-1847$ & 12 & & Gurkhas \\
\hline \multicolumn{5}{|l|}{ Miscellaneous } \\
\hline 36. 抄錄 & $\begin{array}{l}1754-1806, \\
1899\end{array}$ & 108 & Qu omits & unknown \\
\hline 37. 澫洲源流考 & $1760 \mathrm{~s}$ & 5 & & $\begin{array}{l}\text { drafts of chapters } \\
\text { from Manzhou } \\
\text { yuanliu kao }\end{array}$ \\
\hline 38. 朱批檔 & $1767-1813$ & 5 & Qu omits & unknown \\
\hline
\end{tabular}

Source: FHA catalogues; Qu, "Qingdai junjichu Manwen dang'an gaishu." 
The documents categorized under "Banner Affairs" include large numbers of household registers, reports on absconded personnel, and documents relating to selection of palace women (Ch. xiunü, Ma. sargan jui). ${ }^{44}$ The earliest items date from the Yongzheng reign, with the majority from the Guangxu and Xuantong reigns. By far the largest number of documents (well over 10,000 ) is found under "Appointments." These include charts of succession to the captaincy of different companies in all eight of the Manchu, Mongol, and Chinese banners, both in Beijing and in the garrisons; correspondence related to same; also genealogies, requests for leaves of absence, and petitions to retire. "Legal Cases" contains documents relating to 850 incidents (e.g., violent crime, property disputes) involving bannermen that arose between 1712 and 1912 (again, most are from the nineteenth century). Another 41 documents pertain to the selection of bannermen for the constitutional commission formed in 1905. "Military Affairs" contains reports of selection, training, and inspections of banner troops in the capital and provinces. Under "External Activities" are filed, among other things, five documents from the Shunzhi through Qianlong reigns noting gifts from Korean missions and reports on Japan. "Fiscal Affairs" and "Public Works" contain materials on salary and grain payments, expenses, collection of rents, and construction and repair of banner housing, from the 1720s through to 1910. Reports on successful degree candidates and the Eight Banner schools are filed under "Education." Sacrificial texts, documents concerning imperial birthdays, weddings, audiences, and funerals are filed under "Rites."

All in all, though the variety of materials is great, the Eight Banner Command archives do not contain a systematic, cumulative archive comparable to the Grand Secretariat shishu or huangce or the Grand Council lufu zouzhe or yuezhe bao (where much information on the banners may be found). The most extensive single type of document collection is that of genealogies and succession charts (many of these are found in collections abroad as well). Because they were compiled triennially, Eight Banner household registers must have been even greater in number, but it appears that the great majority of these have now been lost for most of the regular banner population in Beijing and China proper. ${ }^{45}$ Nevertheless, used in combination with other materials-

\footnotetext{
44 More Eight Banner household registers are kept with the Board of Revenue Chinese-language archives and in the Imperial Household Department archives.

45 One might note two exceptions. Household registers for banner populations-a large proportion of which was unfree, attached to imperial estates - survive in large numbers for the Northeast (Manchuria). Also, the population registers for the imperial household survive intact. On these materials, see the volume by James Lee (Li Zhongqing) and Guo Songyi, eds., Qingdai huangzu renkou xingwei he shehui huanjing (Beijing: Beijing University Press, 1994) and James Lee and Cameron Campbell, Fate and Fortune in Rural China: Social Organization and Population Behavior in Liaoning, 1774-1873 (New York: Cambridge University Press, 1997).
} 
Table 3: Eight Banner Command Archives by category

\begin{tabular}{|c|c|c|c|}
\hline Item & $\begin{array}{l}\text { No. of } \\
\text { bundles }\end{array}$ & Item & No. of bundles \\
\hline Banner Affairs & 41 & Public Works & 3 \\
\hline Appointments & 482 & Real Estate & 23 \\
\hline Legal Affairs & 23 & Education & 34 \\
\hline $\begin{array}{l}\text { Suppression of Revolutionary } \\
\text { Movements }\end{array}$ & 1 & Rites & 36 \\
\hline $\begin{array}{l}\text { Allied Expeditionary Force } \\
\text { Invasion }\end{array}$ & 2 & General & 2 \\
\hline Military Affairs & 64 & Charts & 15 \\
\hline External Activities & 4 & Other & 73 \\
\hline Fiscal Affairs & 51 & TOTAL & 856 \\
\hline
\end{tabular}

Source: FHA catalogue.

in particular the Lichao baqi zadang and Baqi shixipu dang described earlier - their importance for work on the Eight Banners should not be underestimated.

Imperial Palace Archives. The most important constituent of this record group is without question the palace memorials. While these might be considered as falling within the purview of the Grand Council, which eventually took over their transmission (and made copies of everything), the palace memorial system arose independently of the Grand Council, and the originals (which, after 1722, memorialists were supposed to return to the palace at the end of every year) were stored separately in the palace. Therefore it is customary to treat them as part of the gongzhong record group. Before discussing the palace memorials, however, I would like to introduce some of the other, less well known Manchu-language Imperial Palace archives. These items, while fragmentary in nature and little used, contain many surprises. They are found in two separate catalogues, Gongzhong Manwen zadang (cat. no. 323/4-48) and Gongzhong Manwen zajian (cat. no. 324/4-49), the former consisting mainly of copybooks and files, the latter of original documents. Their contents are summarized in Tables 4 and 5. 
Table 4: Contents of the Gongzhong Manwen zadang

\begin{tabular}{|c|c|c|c|}
\hline Item & Date & No. of ce & Remarks \\
\hline 1. 御前侍衛册 & $165 \mathrm{I}$ & 1 & \\
\hline 2. 奏事檔 & $1696-1697$ & 5 & \\
\hline 3. 康熙至額米勒巡常事件檔 & 1720 & 1 & \\
\hline 4. 日記檔 & Kangxi reign -1792 & 7 & $\begin{array}{l}\text { catalogue says } 35 \\
\text { items, omits } \\
\text { jinbendan }\end{array}$ \\
\hline 5. 記誵旨檔 & $1723-1796$ & 8 & \\
\hline 6. 奏事處亲隹錄楅 & $1729-1735$ & 2 & $\begin{array}{l}\text { catalogue says } 74 \\
\text { items through } \\
\text { Guangxu }\end{array}$ \\
\hline 7. 左在凟射筒中靶檔 & 1735 & 11 & \\
\hline 8. 白意檔 & $\begin{array}{l}\text { Yongzheng - } \\
\text { Daoguang reigns }\end{array}$ & 4 & $\begin{array}{l}\text { catalogue says } \\
\text { through Guangxu }\end{array}$ \\
\hline 9.綿虫郎 & $1742-1796$ & 16 & \\
\hline 10. 值琲檔 & $1742-1873$ & 128 & \\
\hline 11.八旗都統衙門六項則例 & 1765 & 1 & \\
\hline 12. 綠頭牌樣簿 & 1849 & 1 & \\
\hline 13. 祭文底簿 & Guangxu reign & 1 & \\
\hline 14. 人名雜錄楅 & n.d. & 4 & \\
\hline 15. 批本處培存事件檔 & n.d. & 3 & \\
\hline 16. 滿文名人傳栜本 & n.d. & 1 & \\
\hline 17. 官員品級稿本 & n.d. & 2 & \\
\hline 18. 名官員所欠銀兩數目册 & $\overline{\text { n.d. }}$ & 4 & \\
\hline 19.十二宇頭 & n.d. & $\sqrt{2}$ & \\
\hline 20. 雜檔 & n.d. & 8 jian & \\
\hline TOTAL & & 210 & \\
\hline
\end{tabular}

Source: FHA catalogue. 
Table 5: Contents of the Gongzhong Manwen zajian

\begin{tabular}{|c|c|c|c|}
\hline Item & Date & No. of jian & Remarks \\
\hline 1. 朱批票簽 & $1671-$ & $\sim 6,807$ & \\
\hline 2. 御製碑文紀(經朱改) & $\begin{array}{l}\text { Kangxi - Qianlong } \\
\text { reigns }\end{array}$ & 65 & $\begin{array}{l}\text { inaccurately } \\
\text { catalogued }\end{array}$ \\
\hline 3. 榶單 & $\begin{array}{l}\text { Kangxi - Daoguang } \\
\text { reigns }\end{array}$ & 2,207 & \\
\hline 4. 朱諭 & $\begin{array}{l}\text { Kangxi - Xianfeng } \\
\text { reigns }\end{array}$ & 356 & \\
\hline 5. 朱批奏摺 & $\begin{array}{l}\text { Kangxi - Guangxu } \\
\text { reigns }\end{array}$ & 2,110 & \\
\hline 6. 諭旨雁奏 & $1723-1911$ & 1,218 & \\
\hline 7. 籍注 & Yongzheng reign & 57 & \\
\hline 8. 陪祀單 & 1748-ca. 1911 & 388 & \\
\hline 9. 朝單 & 1748-ca. 1911 & 6,777 & \\
\hline 10. 奏事處來文 & 1753-ca. 1911 & 498 & $\begin{array}{l}\text { complete for } 1810 \text { - } \\
1812\end{array}$ \\
\hline 11. 記名人員名單 & Guangxu reign & 171 & \\
\hline 12. 請安摺 & n.d. & 905 & \\
\hline 13. 朱批缺單 & n.d. & 1,416 & \\
\hline 14. 朱批簽 & n.d. & 200 & \\
\hline 15. 值班人員名單 & n.d. & $\sim 16,262$ & \\
\hline 16. 㴬恩官員數目單 & n.d. & 78 & \\
\hline 17. 葉爾姜和田等地伯克頭人 & n.d. & 13 & \\
\hline
\end{tabular}


Table 5: Continued

\begin{tabular}{|l|l|l|l|}
\hline 源流 & & & \\
\hline $\begin{array}{l}\text { 18. 中庸大學論語易經詩經翻 } \\
\text { 譯稿 }\end{array}$ & n.d. & 171 & \\
\hline 19. 朱改無量壽佛頌等文 & n.d. & 13 & \\
\hline 20. 碑文底 & n.d. & 60 & \\
\hline 21. 五臺山各寺數目單 & n.d. & 5 & \\
\hline 22. 軍令條約 & n.d. & 26 & \\
\hline 23. 朱改聖訓序等文 & n.d. & 43 & \\
\hline 24. 蒙文字頭課本等 & n.d. & 10 & \\
\hline 25. 佛經等 & n.d. & 36 & \\
\hline TOTAL & & $\sim 39,907$ & \\
\hline
\end{tabular}

Source: FHA catalogue.

A number of the Manwen zadang items (e.g., nos. 2, 4, 5, 6,8, 10) originated in the transmission of documents to and from the palace; they record the arrival of memorials, dates of edicts, personnel on duty, and such information. Others contain material of an appropriately miscellaneous nature, such as a 28-page narrative account of a 1720 incident in the Altai (no. 3), the record of a 1735 archery competition among members of the imperial guardsmen (no. 7), a hand-copied version of regulations for the Eight Banner command office (no. 11), and the workbook of a certain Sanciowan for practicing handwriting (no. 19). Though there are some similarities, the contents of the Manwen zajian are yet more diverse. There is a large number of palace memorials, some of which do not appear to have been included in the published translations of Manchu memorials (more on this below); drafts of inscriptions (e.g., for stelae at temples, tombs, military commemorations, the Yuanming yuan), as well as drafts of sacrificial texts and translations (e.g., of the Chinese classics and Buddhist texts). These latter are complete with changes made by the imperial brush. 


\section{The Manchu-language Palace Memorials and the Origins of the Palace Memorial System}

For sheer pleasure of handling there is little to compare with the Qing palace memorials, some even with brilliant brocade covers, written in precise calligraphy on fine paper and capped by a dramatic vermilion flourish at the end. As others have pointed out, they are also a great pleasure to read, particularly those from the early and middle Qing, when the palace memorials were the prime means of direct personal communication between the active, involved sovereign and his servitors. ${ }^{46}$ Given that a bond of ethnic solidarity tended to characterize the emperor's relationship with his Manchu officialswith whom, of course, he preferred to communicate in Manchu - the Manchu palace memorials offer a unique window onto different aspects of Qing rule. ${ }^{47}$ This section offers a detailed analysis of the whereabouts of the Manchu palace memorials and a reconsideration of the origins of the palace memorial system with reference to some of the earliest surviving documents.

\section{The Manchu-language Palace Memorials}

The exact number of Manchu-language palace memorials that survive in the archives is unknown. The Kangxi-, Yongzheng-, and Qianlong-era Manchu palace memorials probably constitute the majority of those extant, but until we learn more about the nineteenth-century portion, this remains uncertain. For the Kangxi reign, of the total 10,000 palace memorials extant, approximately 5,800 are in Manchu. Of these, some 700 are in the NPM archives in Taipei; these have all been published in facsimile. ${ }^{48}$ The remainder is all in the FHA; translations of most of these documents have been published, together with translations of the Taipei Manchu memorials. For the Yongzheng reign, there is a total of about 33,000 palace memorials, of which about 6,800 are in Manchu: 1000 or so are in the NPM and 5,800 in the FHA. The former have been published in facsimile and have now been translated into Chinese, together with most of the FHA memorials. For the Qianlong reign, numbers are much less certain. Since the memorials of each of these three reign periods are catalogued separately in the FHA, I will describe each in turn.

Manchu palace memorials from the Kangxi reign in the FHA are found in three different catalogues: Kangxi chao Manwen zhupi zouzhe mulu (cat. no. 508/4-92), Kangxi chao Manwen zhupi zouzhe jigoubao mulu (no catalogue

See Bartlett, Monarchs and Ministers, passim.

See Elliott, The Manchu Way, 160-71.

48 Not all of the Manchu documents published in the NPM Gongzhongdang volumes are in fact palace memorials (twelve of the first fifteen in Vol. 8 of the Kangxi-reign memorials are not), but for present purposes I will count them as such. 
number), and Gongzhong Manwen zajian mulu (cat. no. 324/4-49; see Table 5 , no. 5 above). The first catalogue contains 4,493 palace memorials, divided among 516 entries. 32 entries are identified only by category (the 18 topics) and 484 by memorialist and then category. In the 32 category-only entries are 210 memorials; in the 484 memorialist + category entries are 4,283 memorials, spread among 91 memorialists. More than one-quarter of these 91 have more than 50 memorials to their names, several (including two imperial sons) with over 100 . In addition to this main catalogue, there is a secondary catalogue, identified as jigoubao, as its contents are classified according to the department that submitted the memorial, not the person. In this catalogue (divided into 33 entries) are found an additional 444 Manchu-language palace memorials from the Kangxi reign. ${ }^{49}$ Finally, there is Gongzhong Manwen zajian mulu, which contains 111 items, many in very fragile condition.

Total Kangxi-period Manchu palace memorials: 5,048 items (5,789 including 741 items in the NPM).

Manchu palace memorials from the Yongzheng reign are listed in four different catalogues. The most important is Yongzheng chao Manwen zhupi zouzhe fenlei lijuan mulu (cat. no. 506/4-90). The first part of this catalogue, with 1,970 documents, is divided according to category (for details, see Table 6). The second part, with 3,524 documents,${ }^{50}$ is divided according to memorialist, of which there are 271 . Since for $90 \%$ of memorialists fewer than fifty memorials remain, the Yongzheng collection is on the whole more dispersed than the Kangxi collection. The second catalogue, a subset of the first distinguished only by the additional label yileijia (cat. no. 505/4-89), lists 107 documents, many having to do with frontier and border affairs. One would not think to look here, but Kangxi chao Manwen zhupi zouzhe jigoubao mulu is a third catalogue containing Yongzheng palace memorials, with entries for 153 documents. An additional 63 memorials from the Yongzheng reign are found in the Gongzhong Manwen zajian catalogue.

Total Yongzheng-period Manchu palace memorials: 5,817 items $(6,811$ including 994 items in the NPM).

Cataloguing of Manchu memorials from the Qianlong reign is still very rough. For now, documents are listed in three catalogues. The two most important are Gongzhong Manwen zhupi zouzhe dengji mulu (cat. no. 158/419-12) and Gongzhong Manwen zhupi zouzhe caomu (cat. nos. 158/4-19-1 through 4-19-10). Both of these list materials that have remained essentially undisturbed since they were wrapped for storage in the eighteenth century.

49 This includes 95 items that appear in the catalogue as undated (packet 26) but which in fact bear dates from the Kangxi era.

so The catalogue claims 3,618 , but this would appear to be an arithmetical error. 
Table 6: Sample distribution of Yongzheng-period Manchu palace memorials

\begin{tabular}{|c|c|c|c|c|c|c|c|c|c|}
\hline $\begin{array}{l}\text { Type } \\
\text { Date }\end{array}$ & 内政 & 財政 & 軍務 & 民 族 & 法律 & $\begin{array}{l}\text { 交通 } \\
\text { 工程 } \\
\text { 工業 }\end{array}$ & $\begin{array}{l}\text { 農業 } \\
\text { 水利 }\end{array}$ & 其他 & Total \\
\hline 1723 & 163 & 33 & 117 & 39 & 4 & 1 & 8 & 30 & $395(20 \%)$ \\
\hline 1724 & 115 & 21 & 52 & 6 & 11 & 8 & 17 & 2 & $232(12 \%)$ \\
\hline 1725 & 30 & 10 & 56 & 6 & 15 & 1 & 5 & 2 & $125(6 \%)$ \\
\hline 1726 & 30 & 7 & 47 & 7 & 4 & 1 & 2 & 1 & $99(5 \%)$ \\
\hline 1727 & 106 & 3 & 61 & 10 & 1 & -- & 1 & - & $182(9 \%)$ \\
\hline 1728 & 111 & 4 & 198 & 1 & -- & -- & 2 & -- & $316(16 \%)$ \\
\hline 1729 & 26 & 6 & 22 & 2 & 4 & 4 & 1 & 2 & $67(4 \%)$ \\
\hline 1730 & 25 & 5 & 13 & 8 & 1 & 2 & -- & 2 & $56(3 \%)$ \\
\hline 1731 & 1 & 2 & 7 & 5 & -- & - & -- & - & $15(1 \%)$ \\
\hline 1732 & 6 & 3 & 11 & 18 & 2 & - & - & -- & $40(2 \%)$ \\
\hline 1733 & 16 & 2 & 37 & 2 & 2 & 1 & 3 & -- & $63(3 \%)$ \\
\hline 1734 & 83 & 5 & 100 & 3 & 4 & 1 & 2 & 6 & $204(10 \%)$ \\
\hline 1735 & 57 & 11 & 68 & 3 & 3 & 1 & 6 & -- & $149(8 \%)$ \\
\hline $\begin{array}{l}\text { no } \\
\text { date }\end{array}$ & 8 & 2 & 12 & 3 & 2 & 1 & - & - & $28(1 \%)$ \\
\hline Total & $\begin{array}{l}777 \\
(39 \%)\end{array}$ & $\begin{array}{l}114 \\
(6 \%)\end{array}$ & $\begin{array}{l}801 \\
(41 \%)\end{array}$ & $\begin{array}{l}113 \\
(6 \%)\end{array}$ & $\begin{array}{l}53 \\
(3 \%)\end{array}$ & $\begin{array}{l}21 \\
(1 \%)\end{array}$ & $\begin{array}{l}47 \\
(2 \%)\end{array}$ & $\begin{array}{l}45 \\
(2 \%)\end{array}$ & $\begin{array}{l}1,971 \\
(100 \%)\end{array}$ \\
\hline
\end{tabular}

Source: FHA Yongzhengchao Manwen zhupi zouzhe fenlei lijuan catalogue. 
The first catalogue contains listings for 680 packets ( $\mathrm{bao}$ ) of Qianlong-era Manchu palace memorials. Packets are ordered by date only, and average about eleven per year. The precise total number of memorials this represents is hard to say, as an individual packet may contain as few as five or as many as one hundred items. My estimate is that there are approximately 27,200 documents in this group. ${ }^{51}$ The materials in the second catalogue (which is in ten volumes) appear all to date from 1754 or later. They are ordered internally not by date but by memorialist, arranged according to Manchu alphabetical order (words beginning with vowels, words beginning with $\mathrm{n}$, with $\mathrm{k} / \mathrm{g} / \mathrm{h}$, with $\mathrm{b}$, etc.). A total of 20,912 Manchu palace memorials are listed here (see Table 7).52 The third catalogue with Qianlong palace memorials is the Gongzhong Manwen zajian catalogue, with 448, in seven packets. The earliest of these are from the first year of the Qianlong reign, and go through the 1770s.

Total Qianlong-period Manchu palace memorials: 48,560 (48,750 including 190 items in the NPM).

From the Kangxi, Yongzheng, and Qianlong reigns, then, there remain a total of about 61,350 Manchu palace memorials. There are, in addition, an unknown number from later reigns. The Gongzhong Manwen zhupi zouzhe dengji catalogue lists 452 packets of Manchu memorials from the Jiaqing reign, 241 from the Daoguang reign, 125 from the Xianfeng era, 13 from the Tongzhi era, and 14 from the Guangxu reign. If we estimate using the same average number of documents per packet (40) as before, these 845 packets contain another 33,800 palace memorials. This would bring the total number of Manchu palace memorials to over 95,000. This is admittedly greater than the FHA's own estimate of "over 80,000" Manchu palace memorials for all reigns, ${ }^{53}$ and so might be taken as a high-end figure. Assuming these estimates are roughly correct, this would mean that Manchu palace memorials account for between $14 \%$ and $16 \%$ of all palace memorials in the FHA (there are 488,777 Chinese-language zouzhe), and around $12 \%$ of the total 727,000 palace memorials in both the FHA and NPM. This is consistent with the overall proportion of Manchu-language archives as a whole for the Qing. As time goes by and more detailed cataloguing becomes possible, more accurate numbers will undoubtedly become available, particularly for the Qianlong and later reign periods.

\footnotetext{
51 This estimate is derived by multiplying the total number of packets (680) by an estimated average number of documents per packet (40). I arrived at this average by dividing the approximate number of documents $(4,539)$ contained in a total 114 packets I examined dating from between 1736-1760.

52 The last two of the twelve word-initials (Ch. shi-er zitou, Ma. juwan juwe ujui bithe) are not represented in these ten volumes, leading one to suspect that at least one other "name packet" (renming bao) may exist (this is confirmed by the numbering sequence, which is missing no. 4-19-11).

${ }_{53}$ This and following figures are taken from the introduction to Qingdai zhupi zouzhe caizhenglei mulu, First Historical Archives, comp. (Beijing: Zhongguo caizheng jingji chubanshe, 1990), 2.
} 
Table 7: Gongzhong Manwen zhupi zouzhe caomu (Qianlong reign)

\begin{tabular}{|l|l|l|l|}
\hline Catalogue no. & No. of memorials & No. of memorialists & Well-known officials \\
& & & represented \\
\hline $158 / 4-19-1$ & 3,025 & 19 & Agūi, Amursana \\
\hline $4-19-2$ & 3,330 & 11 & \\
\hline $4-19-3$ & 1,001 & 20 & Ohüi, Udašan \\
\hline $4-19-4$ & 2,140 & 22 & Nayantai, Hailanca \\
\hline $4-19-5$ & 1,635 & 21 & \\
\hline $4-19-6$ & 2,375 & 17 & Bandi \\
\hline $4-19-7$ & 1,838 & 28 & Songyun \\
\hline $4-19-8$ & 2,706 & 17 & Šuhede \\
\hline $4-19-9$ & 2,069 & 43 & Dafu \\
\hline $4-19-10$ & 793 & 17 & Leboo \\
\hline Total & 20,912 & 215 & \\
\hline
\end{tabular}

\section{Chinese Translations of the Manchu Palace Memorials}

As noted above, the Manchu palace memorials from both the Kangxi and Yongzheng reigns have recently been translated into Chinese. The result of many years' hard work by the Manchu Section staff of the FHA, their appearance is to be greatly applauded, as they inform the wider scholarly community of the very rich content of these historical sources. Researchers who would be unable to make use of them in the Manchu original should be especially pleased that so much new material is now available in Chinese. At the same time, these documents must be approached with all the caution one would normally reserve for any translation. Following are some brief comments on the problems facing the scholar who wishes to make use of these valuable resources.

First of all, it needs to be said that a translation project such as this requires a tremendous amount of dedication and diligence. The sheer volume of the material is daunting - the translations run to 27 million characters (for the Kangxi memorials) and 47 million characters (for the Yongzheng memorials) each! Added to this are the other challenges of deciphering unclear orthography and unraveling obscure terminology in order to figure out what was meant 
in the original and how best to say it in another language. This is no easy task, as anyone who has tried translating Manchu documents can testify, and any translation inevitably incurs occasional lapses, especially when the scale of the project is great, as in this case.

My own close comparison of twenty or so translations of individual documents with the Manchu originals persuades me that they are, on the whole, accurate and reliable. One difficulty I have discovered has to do, not with outright mistakes (there are few of these $\mathrm{e}^{54}$ ), but with interpretations of uncertain passages. I will cite just a few examples from a very early palace memorial from the twelfth year of the Kangxi reign (dated KX12.11.29 = 5 January 1674) from Šanggitu, Director of Palace Storehouses. The Manchu text of this item is as follows:

wesimburengge..

dorgi ku-i icihiyara hafan amban šanggitu sei gingguleme wesimburengge..

donjibume wesimbure jalin. juwan biyai ice jakūn de. taigiyan yang ce.

dergi hese seme. šanggiyan ulhu jakūnju gamaha..

juwan emu de. haha juse nartai.

dergi hese seme. menggun dehi yan gamaha..

tofohon de. taigiyan yang ce. taigiyan li ši oi be takūrafi. dergi hese seme. mao kin diyan de baitalara teišun-i obokū emke gamaha..

juwan jakūn de. gu taigiyan.

dergi hese weile seme. teišun-i teile muwašame. muhaliyan

fuhešere. hiyūn lu emke weilefi gamaha..

orin uyun de. taigiyan yang ce. taigiyan lio wen šeng be takūrafi.

dergi hese seme. bosho durun-i teišun-i tilu emke

gamaha.. erei jalin gingguleme

donjibume wesimbuhe..

elhe taifin-i juwan juweci aniya omšon

\footnotetext{
54 One such apparent error is found in the translation of a 1723 memorial from Jingzhou garrison general Unaha. The original text of the question in passage reads: "nikasa de ume basubure ele ginggule ele olhošo." The FHA translators render this as follows: wu chaonong Hanren, yi jia jinshen ("Do not ridicule the Chinese, [but] increase caution"). The dative-locative particle $d e$ and the causative form of the verb basumbi, "to ridicule," make it clear, however, that the object of the verb is not "Han Chinese" (Ma. nikasa) but the recipient of the message, i.e., Unaha. The implication of the subsequent words (on "caution") is also quite different. Thus a correct literal translation of this passage would be, "No getting ridiculed by the Chinese. The more [they] respect [us], the more [they will be] cautious." The Manchu original is found in FHA, Yongzheng Manwen zhupi zouzhe, packet 509, Unaha, YZ1.9.25; the Chinese translation is in Yongzheng chao Manwen zhupi zouzhe quanyi, no. 700, p. 381.
} 
biyai orin uyun.

menggun. furdehe jurgan-i icihiyara hafan

amban šanggitu.

icihiyara hafan bime. emu jergi wasimbuha

amban martai.

Rescript (on front, in Chinese): zhidaoliao $^{55}$

My translation of this memorial runs:

Memorializing. Department Director of Palace Storehouses Sanggitu et al., reverently memorializing.

Reporting matter: On the eighth [day] of the tenth month, the eunuch Yang Ce, citing an imperial edict, took away eighty white ermine pelts. On the eleventh [day], the haha juse Nartai, citing an imperial edict, took away forty taels of silver. On the fifteenth [day], the eunuch Yang Ce sent the eunuch Li Shiyu and, citing an imperial edict, took away one copper basin used in the Maoqin palace. On the eighteenth [day], the eunuch $\mathrm{Gu}$, citing an imperial edict saying, "Make [it]," took pure copper [and], crudely rolling it into a sphere, made it into an incense burner and took it away. On the twenty-ninth [day], the eunuch Yang Ce sent the eunuch Liu Wensheng and, citing an imperial edict, took away one kidneyshaped copper portable heater. On these matters we reverently present a report.

Twenty-ninth day of the eleventh month of the twelfth year of "Universal Peace."

Sanggitu, Department director of the imperial silver and fur store houses.

Martai, Department director, elevated one rank. Rescript (on front, in Chinese): Acknowledged.

The Chinese translation of this text appears as follows: ${ }^{56}$

\footnotetext{
55 FHA, Kangxi chao Manwen zhupi zouzhe jigou bao, packet 26. Single and double periods, corresponding to partial and full stops, represent the original punctuation. Proximity to the left margin indicates text elevation in the original, which is $6.5 \times 15 \mathrm{~cm}$ in size.

56 Translated from text in Kangxi chao Manwen zhupi zouzhe quanyi, p. 3.
} 


\begin{abstract}
朱批：知道了
內庫郎中臣尚吉圖等謹奏：為奏聞事。

䆚照十月初八日, 太監楊徹指稱上諭領銀鼠皮八十張以去。十一日, 男童 納爾泰指稱上諭領銀四十兩以去。十五日，太監楊徹派太監李世玉指稱上 諭領惁勤殿所用銅洗臉盆一個以去。十八日, 顧太監指稱上諭, 製造銅粗 圓轉熏爐一個帶去。二十九日，太監楊徹派太監劉文生指稱上諭領銅腰提 爐一個。為此謹具奏聞。

銀庫, 皮庫郎中臣尚吉圖, 郎中降一級大臣馬爾岱。
\end{abstract}

At first glance, this translation seems fine. Yet there are at least three areas where one might raise questions. First, the phrase haha juse is an unmistakably plural form, but the name of only one boy (Nartai) is given in the document. Either there were other, unnamed, boys involved, or, more likely, haha juse here is not being used in its literal sense ("boys"), but in the special sense of "young male attendant" or "page." Using a method widely applied to unfamiliar Manchu terminology, Chinese-language documents from the early Qing sometimes render this term phonetically, writing ha-ha zhu-zi or ha-ha zhusai when it was clear that "page" was the intended meaning. Though a minor point, one might like to have seen this possible ambiguity somehow indicated in the text of the translation (there are no footnotes here or anywhere in the volume suggesting uncertainty of meaning). The second problematic passage follows in the entry for the $18^{\text {th }}$ day. How should we understand "gu taigiyan. dergi hese weile seme. teišun-i teile muwašame. muhaliyan fuhešere. hiȳun lu emke weilefi gamaha.."? The Chinese translation in the FHA, which omits the one-word content of the edict to eunuch $\mathrm{Gu}$, says that he made a "crude revolving incense burner of copper" and took it away. An alternative reading of this passage suggests that the eunuch Gu rolled (Ma. fuhešembi) the copper to make the incense burner, and not that the incense burner itself revolved ("revolve" in Manchu is usually expressed by the verb forgošombi). The third place where the translation might be questioned comes in the translation of bosho durun-i teišun-i tilu. Absent from Manchu dictionaries, tilu is evidently a borrowing from Chinese. The Chinese translation says only that a "waist portable heater" (Ch. yao tilu) was taken, and gives no information as to its appearance. The word yao can, of course, mean kidney, but it is not clear from the FHA translation that the copper heater was in fact in the shape of a kidney (as opposed to being a heater one might use to warm one's back). 
In all these cases, the decision not to include facsimiles or transcriptions of original texts, which would have made it possible to double-check important passages, is a serious omission. One also regrets the decision to disregard the original look of documents (including the color of imperial rescripts, which are in blue or black ink during mourning), to omit the raising of lines (Ch. taitou), and to introduce new paragraphing. For example, a 1709 memorial of Cisinu, document number 1430 in Kangxi chao Manwen zhupi zouzhe quanyi, is noted there as bearing a vermilion rescript (Ch. zhupi, Ma. fulgiyan fi), when in fact the rescript is in black: "saha. ereci amasi jeku maise-i erin- $i$ hüda be wesimbure jedz de ara." ${ }^{77}$ (The Qianlong emperor's rescripts on lateYongzheng memorials are, however, noted as being in black ink.) A 1722 memorial from Huang Bing, document number 287 in Yongzheng chao Manwen zhupi zouzhe quanyi, carries an imperial rescript, but there is no note here that this is not actually a translation (the original rescript is in Chinese). ${ }^{58}$ All of these elements combine to put the original Manchu text at some remove from the reader.

This problem of distance is compounded when one confronts the language of the translations. In general the translators have chosen to reproduce in the Chinese versions language that is similar to Chinese-language palace memorials. In many ways, this is a sound decision. One would not expect imperial proclamations to be translated into English as, "I was thinking about things the other day, and I decided ...." However, the result is that the feel of the translated Chinese text differs considerably from that of the Manchu original. The classical Chinese language used by the officials of the empire possessed tremendous power and dignity, and its vocabulary was austere and commanding. Manchu, on the other hand, only acquired an alphabet in 1599 and had no classical repertoire to back it up. It was just not possible to write with the same adroit elegance in Manchu. While it may thus fairly be said that Manchu lacked majesty, it had a refreshing vigor and directness; the use of grammatical particles and verbal conjugations further abetted clarity of meaning. As a result, the language of the Manchu palace memorials borders on the colloquial, and often lapses into it. For example, the emperor referred to himself simply as "I" (Ma. bi) - there being no imperial "We," no equivalent to the Chinese zhen at his disposal. Manchu officials were supposed to refer to themselves as "[your] slave" (Ma. aha), but as often as not they also referred to themselves also as "I" within texts. The distance between ruler and servant was thus much diminished in Manchu-language documents. All of this is lost in translation. It is true, of course, that the Manchu palace memorials are not

57 FHA, Gongzhong Manwen zajian packet no. 1 (KX48.6.8).

58 FHA, Yongzheng chao Manwen zhupi zouzhe, packet 22, memorial of Hūwang Bing. 
literary monuments. But it is not hard to see how translating them into Chinese - as convenient as it makes things for most Qing historians - fundamentally alters the original nature of these materials and robs them of the novel perspective they give when read in Manchu.

The third, and in some ways most serious, problem with the translated Manchu palace memorials is that of completeness. For example, there is a considerable discrepancy between the total number of Kangxi-period memorials extant $(5,789)$ and the total number of memorials translated in the 1996 Kangxi chao Manwen zhupi zouzhe quanyi $(4,297)$. It seems that this "complete translation" is in fact not so complete, after all. 132 of the missing 1,492 memorials are accounted for when we discover that only 609 of the 741 NPM documents were included for translation in the volume published by the FHA. ${ }^{59}$ As for the rest, the compilers themselves explain in the introduction to the volume that they elected not to include for translation greetings memorials (Ch. qing'an zhe, Ma. elhe be baibure jedz) "of no historical value," i.e., items deemed to be of an entirely routine nature, carrying one of two perfunctory responses from the emperor ("mini beye elhe" [I am fine] and "saha" [Acknowledged]). Whatever one makes of this judgment, there is no information as to how many items were thereby dropped. One would like to think that this explains the absence of the remaining 1,360 memorials. But it appears there are lacunae that cannot be accounted for this way: a spot check of Kangxiperiod documents reveals that at least 42 memorials sent between 1707 and 1721 are somehow missing from the FHA translations volume. ${ }^{60}$ Some, though by no means all, of these are greetings memorials, and even the greetings memorials carry unusual rescripts that render them of definite "historical value." There are also gaps in the Yongzheng translated volumes, where 5,434 out of the total 6,811 memorials appear. Most of the missing 1,377 are no doubt greetings memorials. Yet a random check of memorials for the twelfth year of the Yongzheng reign (1734), reveals that at least sixteen different items - none of them greetings memorials - are absent. ${ }^{61}$ For these reasons, until a complete facsimile edition becomes available, historians seriously interested in utilizing the Manchu palace memorials are better off traveling to

\footnotetext{
59 This is my conclusion after a close comparison of the FHA and NPM volumes.

60 Including those of Yentai (packets 240 and 241), G'oli (packets 261 and 262), Nentei (packet 272), Centai (packet 284), and Toolai (packet 294).

${ }_{61}$ By memorialist/date, these are Wanggüri/YZ1.8.4, Farsan/YZ12.2.2, Asan/YZ12.4.12, Jangge/ YZ12.4.20, Mantai/YZ12.4.29, Bašinu/YZ12.6.3, Mingxan/YZ12.6.10, Samboo/YZ12.6.16, Lioge/ YZ12.6.27, Hesing/YZ12.8.6, Jangge/YZ12.8.28, Fobiyoo/YZ12.9.10, Delfin/YZ12.10.15, Buyantu/ YZ12.10.17, Gendusehe/YZ12.11.5, and Jartai/YZ12.12.22. In addition, two reports by Tulišen on negotiations with Russia (both dated YZ5.7.8, in packet 45 of Gongzhong Manwen zajian) appear to have been omitted, along with a memorial from Cingfu (YZ13.4.26) on talks with Galdan Cereng. I personally examined all of these items on visits to the FHA in 1990 and 1995.
} 
the FHA and consulting materials first hand, using the translation volumes as a guide to their content. ${ }^{62}$

Whatever their limitations, the translations of the Kangxi and Yongzheng palace memorials nonetheless represent a major step forward in promoting the importance of Manchu-language archives for research on the Qing. The Kangxi volume in particular helps advance our knowledge of the beginnings of the palace memorial system. Until recently it has been supposed that the first palace memorials were sent in August 1693, when the Kangxi emperor requested the bondservants $\mathrm{Li} \mathrm{Xu}$ and $\mathrm{Cao}$ Yin to provide him confidential information on miscellaneous developments in the provinces. ${ }^{63}$ But it is clear now from this volume that palace memorials in Manchu were already being sent twenty years before this. ${ }^{64}$ In the remainder of this essay, I would like to review the beginnings of the palace memorial system in the light of recently discovered early Manchu documents.

\section{Reconsidering the Origins of the Palace Memorial System}

Previous treatments of the rise of the palace memorial system have stressed the high degree of secrecy afforded by this new form of communication. ${ }^{65} \mathrm{In}$ contrast to the relatively insecure system for the transmission of routine memorials (which were sent by the imperial post and subject to the various trans-

\footnotetext{
62 Unfortunately, they are of little use as a finding aid. Neither volume contains any indication whatsoever of a translated document's location in the archives. To track down the original of a given document, one is still required to search from scratch through the different catalogues.

63 Jonathan D. Spence, Ts'ao Yin and the K'ang-hsi Emperor: Bondservant and Master (New Haven: Yale University Press, 1966), 225.

64 This point has been made in two separate essays by Guan Xiaolian: "Qing Kangxi chao Manwen zhupi zouzhe chuyi," 84-90, and "Zailun zouzhe qiyuan ji qi tedian," paper delivered at the Second Conference on Ming-Qing Archives and Historical Research to Commemorate the $70^{\text {th }}$ Anniversary of the Founding of the First Historical Archives, Beijing, October 1995.

${ }_{65}$ See John K. Fairbank and Ssu-yu Teng, "On the Transmission of Ch'ing Documents," Harvard Journal of Asiatic Studies (1940), 2-71; Silas H.L. Wu, "The Memorial Systems of the Ch'ing Dynasty, 16441911," Harvard Journal of Asiatic Studies 27 (1965), 7-75 and Communication and Imperial Control in China: Evolution of the Palace Memorial System, 1693-1795 (Cambridge: Harvard Council on East Asian Studies, 1970), Chuang Chi-fa, Qingdai zouzhe zhidu (Taipei: Guoli gugong bowuyuan, 1979); and Beatrice S. Bartlett, "Ch'ing Palace Memorials in the Archives of the National Palace Museum," National Palace Museum Bulletin 13.6 (January-February 1979). See also Bartlett, Monarchs and Ministers. Palace memorials were written on sheets of paper anywhere from 8 to 24 centimeters high, and of unlimited length, that were folded in concertina style so that they were between 4 and 12 centimeters wide (standard fold size was $24 \times 12 \mathrm{~cm}$ ). The differences in appearance and format between zouzhe and tiben-the most important perhaps being that the latter carried the impress of the memorialist's seal of office while the former did not-are outlined in Wu, Communication and Control, 28-29 and Chuang, Qingdai zouzhe zhidu, 25-26. The Manchu term jedz, a loan from Chinese, much predates the "native" word bukdari (from bukdambi, "to fold"), a calque invented in the Qianlong reign. Apart from the script, there is no difference in the form of Manchu and Chinese memorials, save that Chinese memorials open from left to right, Manchu memorials in the reverse direction.
} 
lation procedures described above), Qing palace memorials were transmitted directly between the memorialist and the emperor by private courier, usually a bondservant of the memorialist. During transport they were placed in tamperproof locked wooden boxes or in envelopes that were glued shut and sealed with wax.$^{66}$ Once at the palace, they were delivered at the Chancery of Memorials (Ch. zoushi chu, Ma. baita wesimbure ba), located near the Qianqing gate at the threshold of the inner palace, rather than at the Transmission Office outside the Forbidden City. This revolutionary way of handling communications made possible the exchange of private messages to and from the throne. That memorialists were obliged to write messages themselves, without turning to others for assistance, further heightened their intimacy. The emperor, too, wrote his own comments personally in red, at which point the rescripted memorial was returned to the sender.

The secrecy assured by the palace memorial system (at least in its early years - it became much less private during the Qianlong reign) encouraged both memorialist and emperor to share sensitive information and undoubtedly contributed to its rapid adoption by the Qing court. ${ }^{67}$ The creation of a broad-based yet confidential intelligence network was of particular importance to the Manchus, who, as alien rulers, were somewhat obsessed with matters of security. Equally important, as Bartlett has pointed out, the palace memorial system allowed the ruler to make decisions on matters without creating precedents that would limit his decision-making freedom in the future. ${ }^{68}$ By the nineteenth century, the palace memorial system had nearly entirely supplanted the routine memorial system — an ironic development, as tiben had originally been a Ming innovation to provide more effective communication with the center than that provided by the earlier zouben system left by the Yuan $^{69}$ - and in 1901 the tiben were discontinued altogether.

While the issue of the secret nature of the Qing palace memorial system thus appears settled, the matter of the system's precise origins is more problematic.

\footnotetext{
66 A photograph of such a box is shown in Bartlett, "Ch'ing Palace Memorials," 5. A detailed description of memorial envelopes is given in Spence, $T s$ 'ao Yin, 220, though he makes no mention of wax seals. I chanced across a few among the documents I examined.

67 Miyazaki Ichisada once suggested that the palace memorial system gained popularity also because it was faster ("Shinchō ni okeru kokugo mondai no ichimen," Tōhōshi ronsō 1 (1947), 1-56). However, this does not seem to have been the case. Routine memorials were supposed to be processed in four days, and, at least before 1728 , tended to arrive more quickly at the capital from the provinces. See $\mathrm{Wu}$, Communication and Control, 28-32, and Bartlett, Monarchs and Ministers, 54-55.

68 Bartlett, "Ch'ing Palace Memorials," 4.

${ }^{69}$ Bartlett, "Ch'ing Palace Memorials," 2-3; Sakurai Toshirō, "Mindai daisōhon seido no seiritsu to sono henyō," Tōyōshi kenkyū 51.2 (September 1992), 1-29. Zouben originating from outside Beijing were called benzhang.
} 
As noted, the 1693 memorials of $\mathrm{Li} \mathrm{Xu}$ and Cao Yin have long been taken to be the earliest communications of their kind and as such have been carefully analyzed for clues as to the system's beginnings. Since Li and Cao often took to appending information on weather and prices to ordinary greetings memorials, Jonathan Spence proposed that the system began in an ad hoc fashion, and that the Kangxi emperor, at once grasping the possible advantages of such confidential reports, ordered them to continue, at the same time cautioning that, "It is absolutely imperative that nobody should know about these memorials." "70 A slightly different hypothesis was put forward by Silas H.L. Wu. Writing, like Spence, well before the publication of the NPM facsimiles (and decades before the FHA translations), Wu accepted that the August 1693 memorial from $\mathrm{Li} \mathrm{Xu}$ was the first palace memorial. Like Spence, $\mathrm{Wu}$ also mentioned that using "personal" memorials as a means of obtaining information about the situation in the provinces was an idea that first occurred to the emperor. Also like Spence, Wu stressed the point that these first memorials from Li and Cao were simple greetings to which the men had just happened to add a bit of local news. Wu went beyond Spence, however, to suggest that this use of the greetings memorial arose out of an old Manchu practice of sending greetings to the head of the banner or to the emperor to formally inquire after their health or convey wishes on auspicious occasions, such as a birthday or the New Year. ${ }^{71}$

There are two problems with this hypothesis. First, it seems unlikely that the practice of sending formal written greetings was actually very common among bannermen for the simple reason that in the early Qing period most bannermen were illiterate. Even in the eighteenth century it was not unusual for highranking officers to have difficulty writing grammatically in Manchu (some never bothered to learn Chinese, either). ${ }^{72}$ It is thus hard to imagine that writing skills were widely shared by ordinary bannermen in the early 1600 s. Moreover, if those who could write were in the habit of sending greetings memorials, one would expect that some might have survived, or that there would be some notice of such a custom. Failing this, the idea that the palace memorial system grew out of a prior Manchu tradition must be put aside. ${ }^{73}$

Others have objected to Wu's hypothesis on other grounds. Chuang Chi-fa noted that the sending of greetings memorials was incumbent, not only upon Manchu bannermen, but also upon government officials, whether Manchu, Mongol, or Han Chinese. He also pointed out that sending greetings memori-

\footnotetext{
70 Spence, Ts'ao Yin, 226.

71 Wu, "The Memorial Systems of the Ch'ing Dynasty," 38-41, Communication and Control, 36. Spence makes no claim that the sending of greetings memorials was a Manchu custom.

72 Cf. the 1780 case of a certain Cuwande, whose ignorance of Chinese impaired his ability to censor dramatic texts for offensive remarks against the Qing. Da Qing gaozong chun (Qianlong) huangdi shilu (reprint Taipei: Huawen shuju), juan 1118: 17b-18a. On changing levels of ability in Manchu, see the examples in Elliott, The Manchu Way.

73 This is also Chuang Chi-fa's conclusion (Qingdai zouzhe zhidu, 23).
} 
als was common practice in the Ming. Such documents, Chuang showed, were typically in the form of a zouben. This was the more personal of the two formats used for communications to the throne in the Ming; the other format, the tiben, was reserved for official business. A telling point in Chuang's analysis is the close similarity he found between Qing zouzhe and Ming zouben. Comparing such details as character elevation, the number of characters per line, the absence of official seals, and formalistic terminology, Chuang convincingly argued that the Ming zouben was the template for the Qing palace memorial. He went on to provide an alternate theory for the origin of the palace memorial system. Rather than seeing it as an accident, Chuang believed that the palace memorials resulted from the deliberate combination of semi-official zouben and informative qingdan lists, known as zhezi. The name zouzhe, he said, is literal evidence of this hybridization. He dated their origin to $1686 .{ }^{74}$

Chuang's case would be stronger if there were more examples of $z$ hezi lists actually included with greetings memorials; the examples he provided are from a time when the use of zouzhe was already well established. Moreover, lists (typically of names) are hardly comparable to the types of secrets revealed in palace memorials. Similarly, the citations Chuang drew on to emphasize the distinction between plain greetings memorials and palace memorials are from a later stage of the evolution of the zouzhe system, when the emperor routinely instructed memorialists to discriminate between greetings memorials, memorials of thanks for imperial benevolence, and secret memorials conveying important information.

The debate, outlined above, on the origins of the palace memorial system left it unclear whether the initial evolution was, as Spence and Wu described it, a transformation of the greetings memorial, or whether, as Chuang described it, a merging, in form and substance, of zouben-type ritual memorials and zhezitype enclosures. Though his discovery of references to zhezi in the Diaries of Activity and Repose would seem to support Chuang, Zhu Jinfu disagreed with both of the above views, claiming that the palace memorial system began in 1681, when the first such references appear. However, as he himself admitted, these $z$ hezi were different in nature from later zouzhe, and were "open" court documents lacking the secrecy that distinguished the palace memorials. ${ }^{75}$ An even earlier start date has been proposed by Guan Xiaolian, who argues on the basis of a passage in the Veritable Records that palace memorials were already in use by 1656 . The passage in question is as follows: ${ }^{76}$

\footnotetext{
74 Chuang, Qingdai zouzhe zhidu, 24-33.

75 Zhu Jinfu, "Qingdai zouzhe zhidu kaoyuan ji qita," Ming-Qing dang'an yu lishi yanjiu, 520-523.

76 Found in Da Qing Shizu zhang (Shunzhi) huangdi shilu (The veritable records of the Shunzhi reign), (reprint ed., Taipei: Huawen shuju, 1964), 102: 3a (SZ13.6.7).
} 
諭。向來科道及在京滿漢各官奏摺俱先送内院。今後悉照部例徑詣宮門陳 奏。

("Edict. Heretofore zouzhe from supervising secretaries and censors as well as Manchu and Han officials in the capital have all been sent first to the Inner Chancellery. Henceforth, in accordance with the precedent set by the Boards, all shall be transmitted via the palace gates.") Because the original edict was almost certainly in Manchu, however, it is difficult to come to any definitive conclusions on the precise meaning of the term zouzhe here. Guan insists that this corresponds to the palace memorial we know from the Kangxi reign. But his argument, that the translators of the Veritable Records would not have been cavalier about their choice of wording, cannot entirely resolve concern on this score. Moreover, Guan's argument (also on the basis of the above passage) that by the 1650s Han Chinese as well as Manchu officials were already in the habit of sending palace memorials is unconvincing, given the absence of any such documents from this time in either language. ${ }^{77}$

So when did the palace memorial system begin? Given that the palace memorial was a Manchu innovation, from a purely logical standpoint it should be expected that such a crucial expansion of channels of personal communication with the emperor began, not in dealings with Chinese officials or culturally hybrid bondservants, but with Manchu officials, and in the Manchu language. Indeed, recent work has borne out this hypothesis, as over one hundred palace memorials that pre-date the $\mathrm{Li} \mathrm{Xu} / \mathrm{Cao}$ Yin series have been discovered in the Manchu holdings of the FHA (Table 8).

Careful study of these documents allows us to make a few observations. First, the number of memorialists is extremely limited. Excluding fragmentary items from before 1689, significant deposits remain for only three people: Isangga, Foron, and Fulata. While it is virtually certain that other materials have been lost, it is fair to conclude that at this early point the privilege of submitting palace memorials was very likely reserved for a small elite consisting entirely of Manchu officials, who wrote in Manchu only (among the few exceptions is a 1689 bilingual memorial from Isangga). After 1693, the

\footnotetext{
77 Guan, "Zailun zouzhe qiyuan ji qi tedian," 3-4. On the whole, the interpretations regarding this controversial edict advanced by Chuang Chi-fa, Ju Deyuan, and Zhu Jinfu remain persuasive. See Chuang, Qingdai zouzhe zhidu, 26; Ju Deyuan, "Qingdai tizou wenshu zhidu," in Ming-Qing dang'an lunwen xuanbian (Beijing: Dang'an chubanshe, 1985), 1004-1005; Zhu, "Qingdai zouzhe zhidu kaoyuan ji qita," 517-518. On the basis of an occurrence of the words mifeng zouzhe (lit., tightly sealed memorials) in a nianpu for the year 1661, Yang Qiqiao earlier also put forward the idea that palace memorials began in the Shunzhi era. See his important study, Yongzheng di ji qi mizhe zhidu yanjiu (Hong Kong: Joint Publishing Company, 1981), 156-157.
} 
Table 8: Early Manchu-language palace memorials

\begin{tabular}{|l|l|l|l|l|}
\hline Memorialist and post & Number of & Date(s) & $\begin{array}{l}\text { Location in } \\
\text { Kangxichao } \\
\text { Manwen zhupi } \\
\text { zouzhe quanyi }\end{array}$ & Archival location \\
\hline $\begin{array}{l}\text { Sanggitu } \\
\text { 尚吉圖 } \\
\text { Director of Palace } \\
\text { Storehouses (Imperial } \\
\text { Household Dept.) }\end{array}$ & 1 & KX12.11.29 & no. 5 & $\begin{array}{l}\text { FHA (jigoubao } \\
\text { catalogue, packet 27) }\end{array}$ \\
\hline $\begin{array}{l}\text { Fiyanggu } \\
\text { 費揚古 } \\
\text { General Commandant of } \\
\text { the Gendarmerie }\end{array}$ & 2 & KX15.1.24, & nos. 6,28 & $\begin{array}{l}\text { NPM (vol. 8 of } \\
\text { Gongzhongdang } \\
\text { Kangxichao zonzhe, } \\
\text { no. 5 and FHA } \\
\text { jigoubao catalogue, } \\
\text { packet 27) }\end{array}$ \\
\hline
\end{tabular}

${ }^{1}$ The status of both of these items as palace memorials is open to question. The first is merely a list of measurements and there seems nothing "secret" about it. Since it is not rescripted, it should probably be considered a zhezi. The second item carries the seal of the Imperial Household Department Director (Fiyanggu's position at the time) and so cannot be a palace memorial, strictly speaking. Two other early Chinese-language memorials, both from 1677 , though published in volume 1 of Gongzhongdang Kangxichao zouzhe, appear to be zouben, not zouzhe.

\begin{tabular}{|l|l|l|l|l|}
\hline Anjuhu & 2 & KX18.10.22, & nos. 11,12 & $\begin{array}{l}\text { NPM (vol. 8 of } \\
\text { Gongzhongdang } \\
\text { Mukden Garrison } \\
\text { General }\end{array}$ \\
\hline
\end{tabular}


Table 8: Continued

\begin{tabular}{|c|c|c|c|c|}
\hline $\begin{array}{l}\text { Tuba 圖巴, } \\
\text { Bandi 班第, and Hailasun } \\
\text { 海拉遜 } \\
\text { Departmental Directors } \\
\text { of the Imperial } \\
\text { Household }\end{array}$ & 3 & $\begin{array}{l}\mathrm{K} \times 24.8 .29, \\
\mathrm{~K} \times 26.8 .8 \\
\mathrm{~K} \times 30.4 .17\end{array}$ & nos. $16,17,44$ & $\begin{array}{l}\text { FHA (jigoubao } \\
\text { catalogue, packet 26) }\end{array}$ \\
\hline $\begin{array}{l}\text { Isangga } \\
\text { 伊桑阿 } \\
\text { Grand Secretary }\end{array}$ & 11 & $\begin{array}{l}\mathrm{K} \times 28.1 .27- \\
\mathrm{K} \times 28.3 .4\end{array}$ & $\begin{array}{l}\text { nos. 18-27 } \\
\text { (bilingual item } \\
\text { of } \mathrm{KX} 28.2 .27 \\
\text { printed only in } \\
\text { Kangxichao } \\
\text { Hanwen zhupi } \\
\text { zouzhe) }\end{array}$ & $\begin{array}{l}\text { FHA (cat. no. 508/4- } \\
92 \text {, packets } 1,19,81- \\
83 \text { ) }\end{array}$ \\
\hline
\end{tabular}

\begin{tabular}{|l|l|l|l|l|}
\hline Foron & 82 & KX28.2.29- & nos. 29-43, & FHA (cat. no. 508/4- \\
佛倫 & & KX33.8.27 & $45-56,61-85$, & 92, packets 136-154) \\
Shandong Governor, & & & $88,90,93-$ & \\
Governor-general of & & & $96,98-103$, & \\
Sichuan \& Shaanxi & & & $107-111$, & \\
& & & $115-116$, & \\
& & & $129-134$, & \\
& & & $137-142$ & \\
\hline
\end{tabular}

\begin{tabular}{|l|l|l|l|l|}
\hline Fulata & 29 & KX31.1.4- & nos. 57-60, & FHA (cat. no. 508/4- \\
傅拉塔 & & KX33.R5.12 & $86-87,89,91-$ & 92, packets 337-343) \\
Governor-general of & & & $92,97,104-$ & \\
Liangjiang & & & $106,112-114$, & \\
& & & $117-128,135-$ & \\
& & & 136 & \\
\hline & 130 & & & \\
\hline
\end{tabular}


circle expanded to include others, such as Han bannermen, bondservants, and imperial sons. It was another ten years before ordinary Han Chinese officials were permitted to send zouzhe.

A second observation is that the precise nature of the earliest memorial, namely, the 1674 communication from Sanggitu, Director of Palace Storehouses (presented in the preceding section), remains problematic. Since there is no seal on this document (which I examined in November 1999), it is clearly not a tiben. It is not simply a list, so it is not a zhezi, either. And since it came from a capital and not a provincial official, it cannot be a benzhang. But it is hard to say on the basis of format alone if it is a zouben, then, or a zouzhe. Given that the memorial originated within the Imperial Household Department, the chances that it was sent circuitously via the Transmission Officewhich was the normal route for zouben - are slim; more likely it never left the palace precincts and was sent directly to the emperor, in which case we are justified in calling it a zouzhe. Yet its content is nothing like what one would expect from a zouzhe. Rather than a wish for good health or a discussion of state secrets, we find here instead an updated inventory of palace stores: ermine pelts, silver ingots, wash basins, censers, and heaters. Why would the emperor have been interested in this kind of apparently mundane information? Were such reports delivered on a regular basis? If so, then beginning when? Why are there not more of them? One also cannot help wondering why the Šanggitu memorial, if indeed it was a zouzhe, was not bundled with other palace memorials for storage (it is filed together with tiben and greetings memorials from the Kangxi period as well as miscellaneous sacrificial texts from the Qianlong reign). For these reasons, it is difficult to classify this anomalous document with certainty. Its identification as a palace memorial must be tentative, and awaits the emergence of other, similar documents from the archives.

One thing that the Sanggitu memorial and the other early memorials can confirm, however, is that the practice of sending direct personal reports to the emperor probably arose first in the Imperial Household Department, where four of the first eight memorials originated. From there it spread to other branches of the government, including officials in the capital (e.g., grand secretaries and board presidents) and the provinces (e.g., governors-general, governors, and garrison generals). It is therefore probably not the case that the palace memorial system began as a way for the emperor to keep himself informed about developments outside Beijing, but as a way to keep himself informed, period. This impression is strengthened when we look at the eleven memorials of Isangga ${ }^{78}$ All of these were sent between mid-February and late March of 1689, during the second Southern Tour, suggesting that the emperor relied

\footnotetext{
78 Little is known about Isangga. A Manchu of the Plain Yellow Banner, he won the jinshi degree in 1655 and served as president of the Board of Rites before being named grand secretary in 1688, a position he held until his death in 1702 .
} 
on this type of communication at least as much for news of the situation at home, in Beijing, as for news of the situation abroad, in the provinces. This is plain from the first of these messages, dated 17 February 1689 (KX28.1.27):

Grand Secretary Isangga respectfully memorializing.

Reporting matter: It has been heard in the capital that the people from several hundred places around Shandong province all came through the night to greet my lord.

An edict was issued forgiving Shandong next year's tax payments. The entire people of the province have only heard that of old Yao and Shun were good kings, but who has seen them? Having now been blessed by magnificent favor, they looked up to behold [your] divine visage.

Those people who sell things alongside the road all did much better business than usual. They are elated, saying that my lord has surpassed Yao and Shun. When the officials and people in the capital heard of my lord's wondrous act, there were also none who were not overjoyed.

At this year's lantern festival the people, as usual, have fallen to careless setting of firecrackers. In obedience to the edict of his imperial father ordering that the roads and streets be guarded in advance and a watch be kept for fire, the crown prince has also issued an edict and every road and street was guarded. There were no incidents of fire or theft. On these matters, I respectfully inform and report.

Twenty-seventh day of the first month of the twenty-eighth year of "Universal Peace." Isangga, Grand Secretary.

(Rescript) Acknowledged. ${ }^{79}$

\footnotetext{
79 Original text: aliha bithei da. amban isangga-i gingguleme wesimburengge. donjibume wesimbure jalin. ging hecen de donjihangge. šandung-ni goloi ududu tanggū ba-i irgen. gemu dobori dulime jifi. ejen be okdoko.. šandung- ni goloi ishun aniyai ciyanliyang be guwebuhe seme hese wasimbuha.. goloi gubci irgen. gemu julge yoo šun be sain han seme donjiha dabala. we sabuha bi.. te ferguwecuke kesi be aliha bime. abkai cira be bahafi hargašaha. jugūn-i unduri uncara jaka irgen-i an-i hüda ci gemu fulu baha. ejen. yoo šun ci dulekebi seme urgunjendumbi seme donjiha.. ejen-i ferguwecuke yabun be. ging hecen de bisire hafan irgen donjifi inu urgunjerakūngge aku... ere aniya hacin-i ucuri irgen an-i poo ciralakū sindame efiyehe.. dele genere de. jugün giya be cirala. tuwa-i baita be seremše seme hese wasimbure. hüwang taidz. han ama-i tacibuha hese be dahame. geli hese wasimbure jakade. jugūn giya be teisu teisu ciralame seremšehebi. tuwa. hülhai baita akü. erei jalin gingguleme donjibume wesimbuhe.. elhe taifin-i orin jakūci aniya. aniya biyai orin nadan de. aliha bithei da. amban isangga. Rescript: saha. From FHA, Kangxi chao Manwen zhupi zouzhe packet 83, Yi-sang-a/neizheng/liyi, KX28.1.27. The emperor's rescript was written on the front of the memorial.
} 
Perhaps the reassurance he derived from memorials such as these prompted the emperor to encourage other officials to submit palace memorials, for soon afterward the number of memorials seems to have increased (at least, a greater number has been preserved). Shandong governor (later governor-general of Sichuan/Shaanxi) Foron also seems to have commenced writing palace memorials during the second Southern Tour, with Governor-general Fulata following just a few years afterward. It was around this point that $\mathrm{Li} \mathrm{Xu}$ and, later, Cao Yin were cut in on the act.

Despite their early date, it seems unlikely that Isangga's were among the first palace memorials. For one thing, their form is completely standardized: they are all the same size, with the same number of columns per fold, and without seals. Furthermore, if Isangga were acting in accordance with a specific imperial directive to write him personally, one would expect some reference to that in the text of his memorials; yet none is found. And what of the emperor's responses? Fully eight of Isangga's eleven memorials are laconically rescripted, "Acknowledged." If these had been the first memorials of their kind, one could reasonably expect the emperor to have responded at greater length, to have expressed surprise ("What sort of communication is this?!") or approbation ("It is good that you are obeying my instructions"), perhaps with the addition of further directions. The blasé one-word imperial reply suggests that the exchange of private memorials between Manchu officials and the emperor was already routinized by 1689 , and that Isangga's notes simply received the "usual" treatment. This, plus their regular appearance, tends to confirm Chuang Chi-fa's idea that palace memorials were adaptations of greetings memorials that were already being used for the unofficial transmission of miscellaneous information. The existence of prior documents, such as Šanggitu's 1674 memorial, which are very similar in appearance to Isangga's, demonstrates, however, that the process of adaptation began ten years earlier than Chuang imagined.

The 1679-1681 exchange between the emperor and Mukden garrison general Anjuhū seems particularly important in this regard. This exchange as it has come down to us consists of seven documents: five edicts and two palace memorials.$^{80}$ The first edict, dated 15 February 1679 (KX18.1.5), deals with Eight Banner personnel and was delivered by the emperor's messenger together with what was called an "oral edict" (Ch. kou-chuan, Ma. anggai hese). The second edict was sent on 22 October 1679 (KX18.9.18), ordering Anjuhü to investigate the presence of gold, silver, copper, tin, and lead ores in the Mukden region and the viability of beginning mining operations. This document is full of language emphasizing its unusual nature and the importance of

${ }_{80}$ All of these documents are in the NPM facsimile volume (nos. 8, 9, 10, 11, 12, 14, 15); the Chinese translations (nos. 9, 10, 11, 12, 14, 15) are in the FHA volume of Kangxi Manchu memorials. 
secrecy: The emperor first noted that he has "secretly decreed" (narhüšame wasimbuha) this response, as the previous memorial (which we do not have) sent by Anjuhū was not marked with a seal, so he could not rescript it and send it back out. After mentioning that he had heard about the possibility of valuable metals in Mukden, he ordered the general to "secretly investigate" (narhüšame fujurulame) and write back with his recommendation. The emperor ended this edict with the words, "by special decree" (cohome wasimbuha).

Anjuhü's response came a month or so later, on 24 November 1679 (KX18.10.22). Making liberal use of the same verb, narhūšambi, ${ }^{81}$ Anjuhū also emphasized the secrecy of the communication, in reply, he said, to the oral edict transmitted to him on the twenty-third day of the ninth month (27 October 1679). From this we learn that the emperor's edict was brought by special messenger (in this case, a scribe named Farsa) to Mukden - a good indication that the entire exchange took place on an improvised basis. The emperor did not rescript this memorial, but chose to respond in a separate edict (KX18.11.10/12 December 1679), instructing Anjuhū to share everything he knew about mineral deposits with the Jilin garrison general-secretly, of course. After about one month, on 18 January 1680 (KX18.12.17), Anjuhū wrote again to the emperor, not about mining issues this time, but on a matter of Eight Banner administration. First quoting an edict he received several months earlier - again, by oral transmission, and again, stressing its secret nature-Anjuhū explained the actions he had taken in response, closing with the words, "secretly and reverently memorialized." This memorial carries two rescripts on the back, one in black and one in red. ${ }^{82}$ The black rescript ordered the memorial returned to the sender; the red rescript added that an edict was to be returned with it at the same time, and that the son of the bondservant Guwamboo, Tabku, should take it with him to Anjuhū, who was to "open it with his own hands and read it" (galai neifi tuwa). What this edict was we do not know, but we can confirm that these communications continued to be carried back and forth by personal messengers.

\footnotetext{
${ }^{81}$ Narhüšambi can also mean "to do finely, exhaustively," which is how the FHA translators have generally chosen to understand it. However, from the context (and from Anjuhü's fears that people might get wind of his inquiries), the sense here definitely seems to be that everything be done, not minutely, but secretly.

82 It seems likely that only one of these "rescripts" was actually a rescript. It was unheard of for the emperor to rescript the same memorial using two different colors. As already noted, black was used only in mourning, at which time red could not be used. Thus either the two rescripts were made on separate occasions (one falling during a mourning period and one outside it), or the red rescript is the emperor's and someone else wrote the other comment in black. On this point I have benefited especially from discussions with Beatrice Bartlett.
} 
The last items in the exchange were also edicts. The first of these (KX20.12.8/16 January 1682) noted that, with the pacification of the Rebellion of the Three Feudatories, the empire was restored to peace and the emperor wished to visit the tombs of his ancestors in Mukden, regarding which he desired Anjuhū's special assistance:

You [Anjuhū]: Secretly appoint garrison lieutenant general Mudai and some good, capable adjutants to thoroughly explore the routes to be taken, the places to camp, and the places we should go, including the road connecting Fe Ala and Ula. Have them draw a map and then choose one of the accompanying adjutants-let him be a bright fellow - and send him to the capital to deliver it.

The emperor went on to say that he would be making an official announcement once things were all decided, he did not want news of the trip to leak in advance: "Therefore I am sending this edict especially, and very secretly" (cohome umesi narhüšame hese wasimbuha). He then ended on a personal note: "How are you, general?" (jiyanggiyūn-i beye saiyūn).$^{83}$ A couple of months later, in the last extant edict to Anjuhū (KX21.2.2/10 March 1682), the emperor was similarly blunt, brief, and secretive:

Edict to General Anjuhū. I have read what you wrote, item by item. While there is much to what you say, now that Yunnan has been pacified, it will not do to delay for long the day that this great good [news] is passed [along] through a major sacrifice. We here have looked into everything, and it has been decided that we leave on the fifteenth day of the second month. Apart from this, the other things I want to tell you I have passed in an oral edict to the person who came with your memorial. ${ }^{84}$

The consistent emphasis on secrecy, the use of private messengers, the lack of seals, the quick rescript, and the intimate query concerning Anjuhü's health all characterize this exchange of messages as part of a separate, informal communications network. Though it is premature to label this network a "system" at this early date, nonetheless, the reliance here on zouzhe for the confidental transmission of information to and from the throne indicates that the evolu-

83 Transcribed from the text in Gongzhongdang Kangxi chao zouzhe, vol. 8, no. 14.

84 Transcribed from the text in Gongzhongdang Kangxi chao zouzhe, vol. 8, no. 15. 
tion of the palace memorial began at least by the second half of the 1670s. Anjuhū's memorials, which are roughly similar in format to Šanggitu's 1674 memorial, would seem to belong to a transitional phase and suggest some of the steps in the development of this type of correspondence. For instance, there is the apparent hesitation on the part of the emperor to rescript zouzhe, as seen in his 1679 comment that because a memorial bore no seal he could not write on it and would therefore send a separate edict. But only a few months later, the emperor dispensed with formalities and responded directly on the memorial — an important step in making zouzhe personal, efficient, and confidential, since otherwise edicts were normally drafted in the Grand Secretariat. Another hint lies in the repeated remarks on the delivery of oral edicts from the emperor. These confirm the belief that the palace memorial began in the Imperial Household Department, but also suggest specifically that these beginnings involved not just informal written reports, but also commands so confidential it was preferable to commit them only to the memory of a trusted intermediary and not to paper.

Circumventing the formal transmissions apparatus in these ways might not have been seen as a serious breach of process if the matter at hand concerned affairs of the imperial household, and fit also the Kangxi emperor's preference for direct action. At the same time, while these in-house shortcuts were easily adapted to keep any matter (such as mineral deposits) secret from the bureaucracy at large, the inefficiency of a large-scale oral network no doubt soon became apparent. At some point, even the most secret information had to be written down if it was at all detailed, and messengers' memories may not always have been reliable. This would explain why the use of oral edicts is not widely observed later in the Kangxi reign, and why secret written communications - i.e., zouzhe - gradually took their place, eventually becoming the preferred channel for transmitting sensitive information around the empire.

Of course, even these early documents cannot finally settle the question of a precise date for the establishment of the palace memorial system. Quite likely there is none. Thus, until Chinese-language palace memorials from before 1693 turn up, it seems most sensible to assume that the habit of sending zouzhe began gradually, in Manchu, among a few of the emperor's intimates, in the $1670 \mathrm{~s}$ and $1680 \mathrm{~s} .{ }^{85} \mathrm{By}$ the early $1690 \mathrm{~s}$, once its utility had been recognized and a larger circle of officials (still mostly Manchus) had started sending them, the palace memorial network became steadily more regularized and regulated. This initial evolution culminated in the Yongzheng emperor's 1722 decree that officials must return all rescripted zouzhe in their possession to the

\footnotetext{
85 This was Guan Xiaolian's conclusion, too, in 1994. See Guan, "Qing Kangxi chao Manwen zhupi zouzhe chuyi," 90. A year later, as described earlier, he had revised his opinion in favor of a 1656 start date.
} 
palace at the end of every year. Only then can it be said that a palace memorial system came into existence. ${ }^{86}$ The absence of such a requirement under the Kangxi emperor is a good sign that the palace memorial continued until then to be viewed as an informal tool for the exchange of confidences and was still not seen as belonging to the normal chain of communications for government business. It is also one reason that many Kangxi-period zouzhe, Manchu- as well as Chinese-language, were lost, making the effort to understand its origins that much more difficult.

\section{Conclusion}

The study of Qing history barely counted as an area of expertise in traditional Sinology. Its remarkable development during the second half of the twentieth century depended to a great degree on the availability of published materials (facsimile and typeset) in Chinese. The increasing accessibility of unpublished archives - beginning in Taiwan around 1970 and in Beijing around 1980 - has advanced research even further. In the process, the archives have changed the way that many historians work and think. Nowhere is this more evident than in the attitude toward Manchu-language documents. Once assumed to be relevant only for work on the pre-conquest era, the opening of the archives has made it clear how important Manchu materials are to scholarship on the entire Qing period. Where it was previously believed that Manchu documents merely duplicated what was already written in Chinese, we now know that Manchu archives are an important complement to the Chinese archives. Indeed, for research on some subjects - notably the frontier, military history, pre-nineteenth-century foreign affairs, Manchu history and the Eight Banners, and the imperial household - it is becoming apparent that Manchu archives are indispensable. Apart from this, because Manchu materials constitute (according to the best figures we have at present) as much as $15-20 \%$ of the total Qing archival deposit, one cannot rule out the usefulness of Manchu documents on just about any topic, particularly for the seventeenth and eighteenth centuries.

Needless to say, excellent research can still be done on the Qing, as it has been in the past, without reference to Manchu documents. But as intellectual agendas shift, scholars will find it harder to avoid the Manchu archives if they wish to recognize the different voice in which these sources speak. Only in this way will the new explanations and problems we raise be convincing; only

\footnotetext{
86 See the similar judgment of Yang Qiqiao (Yongzheng di, 158). The edict, dated 29 December 1722, was issued two weeks after the Yongzheng emperor ascended the throne; it is cited in Yang, Yongzheng di, 162 , and Guan, "Zailun zouzhe qiyuan ji qi tedian," 10.
} 
in this way can Qing policies and institutions be contextualized fully. For the light they shed on the earliest phase of development of the palace memorial system, the memorials of Šanggitu, Anjuhū, and Isangga are a good illustration of this principle. Not only did palace memorials begin much earlier than previously suspected, but they began for a different reason - to keep the emperor apprised of developments in the palace and the capital-among a different set of people-Manchu officials, not bondservants. The one common point shared with earlier hypotheses is that it seems very likely that the system arose initially in communications with the imperial household. Future research in the Manchu archives, in particular those of the Imperial Household Department, may turn up more evidence to support this conclusion and further demonstrate the gains to be had by using languages other than Chinese to approach the history of the Qing period.

\section{Glossary 1. Titles of published works mentioned in the text}

Baqi tongzhi chuji

Chongde sannian dang

Dalian tushuguan cang Qingdai neige daku sandie manwen dang'an xuanbian

Fuyuan dajiangjun Yunti zougao

Gongzhongdang Kangxi chao zouzhe

Gongzhongdang Qianlong chao zouzhe

Gongzhongdang Yongzheng chao zouzhe

Guanyu Jiangning zhizao Caojia dang'an shiliao

Gugong bowuyuan yuankan

Gugong Taiwan shiliao gaishu

Gugong wenxian

Guoli Gugong bowuyuan diancang Dazangjing Manwen yiben yanjiu

Jilin gongpin
八旗通志初集

崇德三年檔

大連圖書館藏清代內閣大庫 散佚滿文檔案選編

挴遠大將軍允禔奏稿

宮中檔康熙朝奏摺

宮中檔乾隆朝奏摺

宮中檔雍正朝奏摺

關於江寧製造曹家檔案史料

故宮博物院院刊

故宮台灣史料概述

故宮 文獻

國立故宮博物院典藏 大藏經滿文譯本研究

吉林貢品 
Jiu Manzhou dang

Jōkōkitō: Kenryūchō 1

Jōkōkitō: Kenryūchō 2

Jōkōkitō: Yōseichō

Kangxi chao Manwen zhupi zouzhe quanyi

Kangxi tongyi Taiwan dang'an shiliao xuanji

Lishi dang'an

Man-Han Yiyulu jiaozhu

Man-Hanwen Dizang pusa benyuan jing jiaozhu

Manwen laodang (Manbun rōtō)

Manwen Qing benji yanjiu

Manwen Qing shilu yanjiu

Manwen Tu-er-hu-te dang'an

Manxue yanjiu

Manzhou dang'an ziliao

Manzokushi kenyu tsushin

Manzu yanjiu

Minzu yanjiu

Nian Gengyao Man-Han zouzhe yibian

Nian Gengyao zouzhe zhuanji

Qing Yongzheng chao xianghongqidang

Qingchu neiguoshiyuan Manwen dang'an yibian

Qingdai dang'an shiliao congbian

Qingdai Heilongjiang lishi dang'an xuanbian
舊滿洲檔

鑲紅旗檔：乾隆朝1

鑲紅旗檔：乾隆朝2

鑲紅旗檔：雍正朝

康熙朝滿文朱批奏摺全譯

康熙統一台灣檔案史料選集

歷史檔案

滿漢異語錄校注

滿漢文地藏菩薩本願經校注

滿文老㭻

滿文清本紀研究

滿文清實錄研究

滿文土爾扈特檔案

滿學研究

滿洲檔案資料

滿族史研究通信

滿族研究

民族研究

年䋰琵滿漢奏指繹編

年美堯奏㨨專輯

清雍正朝鑲紅旗檔

清初内國史院滿文檔案譯編

清代檔案史料看編

清代黑龍江歷史檔案選編 
Qingdai Sanxing fudutong yamen Man-Han dang'an xuanbian

Qingdai xiqian Xinjiang Cha-ha-er Menggu Manwen dang'an yibian

Qingdai Zhong-E guanxi dang'an shiliao xuanbian Qingdai Zhun-ga-er shiliao chubian

Qingshi ziliao

Sanxing fudutong yamen Manwen dang'an xuanbian

Shengjing Manwen dang'anzhong de lü ling ji shaoshu minzu falü

Shengjing neiwufu liangzhuang dang'an huibian Shengjing xingbu yuandang

Shunzhi nianjian dang

Suijun xingji yizhu

Sun Wencheng zouzhe

Xibozu dang'an shiliao

Xie Sui "Zhigong tu" Manwen tushuo jiaozhu

Yong-Qian liang chao xianghongqidang

Yongzheng chao Man-Han hebi zouzhe jiaozhu

Yongzheng chao Manwen zhupi zouzhe quanyi

Youguan Da-hu-er E-lun-chun yu Suo-lun zu lishi ziliao

Yuan yilai Xizang difang yu zhongyang zhengfu guanxi dang'an shiliao huibian

Zaoqi Zhong-E dongduan bianjie yanjiu

Zheng Chenggong dang'an shiliao xuanji

Zheng Chenggong Manwen dang'an shiliao xuanyi 鄭成功滿文檔案史料選譯
清代三姓副都統衙門

滿漢檔案選編

清代西遷新疆察哈爾

蒙古滿文檔案譯編

清代中俄關係檔案史料選編

清代準噶爾史料初編

清史資料

三姓副都統衙門

滿文檔案譯編

盛京滿文檔案中的律令

及少數民族法律

盛京內務府糧荘檔案匯編

盛京刑部原檔

順治年間檔

隨軍行紀譯注

孫文成奏摺

錫伯族檔案史料

謝遂職貢圖滿文圖說校注

雍乾兩朝鑲紅旗檔

雍正朝滿漢合壁奏摍校注

雍正朝滿文朱批奏摺全譯

有關達呼爾鄂倫春與

索偷族歷史資料

元以來西藏地方與中央政府

關係檔案史料匯編

早期中俄束段邊界研究

鄭成功檔案史料選輯 


\section{Glossary 2. Names and types of archives and catalogues}

Baqi shixipu dang

benzhang

gaodang

Gongzhong Manwen zadang mulu

Gongzhong Manwen zajian mulu

Gongzhong Manwen zhupi zouzhe caomu

Gongzhong Manwen zhupi zouzhe dengji mulu

hei-tu dang

huangce

hukouce

jice

jixin dang

Junjichu Manwen dangbu mulu

Kangxi chao Manwen zhupi zouzhe jigoubao mulu

lichao baqi zadang

lufu zouzhe

Man[wen] piaoqian dang

Manwen zouchi

Menggutang dang

miben dang

Mishuyuan dang

Neige tiben

Neiguoshiyuan dang
八旗世襲譜檔

本章

稿檔

宮中滿文雜檔目錄

宮中滿文雜件目錄

宮中滿文朱批奏摺草目

宮中滿文朱批奏摺登記目錄

黑圖檔

黃冊

戶口冊

祭册

寄信檔

軍機處滿文檔簿目錄

康熙朝滿文朱批奏摺

機構包目錄

歷朝八旗雜檔

錄副奏指

滿〔文〕票籤檔

滿文奏敕

蒙古堂檔

密本檔

祕書院檔

內閣題本

内國史院檔 


\begin{tabular}{|c|c|}
\hline piaoqian & 票 籤 \\
\hline qiansanchao tiben & 前三朝題本 \\
\hline qijuzhu & 起居注 \\
\hline qing'an zhe & 請安摺 \\
\hline qingdan & 清單 \\
\hline Qingwen zadang & 清文雜檔 \\
\hline qingzhe dang & 清摺檔 \\
\hline riji dang & 日記檔 \\
\hline Sanxing fudutong yamen dang & 三姓副都統衙門檔 \\
\hline shangyu dang & 上諭檔 \\
\hline Shengjing jiangjun yamen dang & 盛京將軍衙門檔 \\
\hline Shengjing libu dang & 盛京禮部檔 \\
\hline shishu & 史書 \\
\hline Shuangchengpu dang & 雙城堡檔 \\
\hline silunbu & 搗胡茂 \\
\hline suishou dengji & 隨手登記 \\
\hline tiben & 題本 \\
\hline tiehuang & 帖黄 \\
\hline yifu dang & 議復檔 \\
\hline $\begin{array}{l}\text { Yongzheng chao Manwen zhupi zouzhe } \\
\text { fenlei lijuan mulu }\end{array}$ & $\begin{array}{l}\text { 雍正朝滿文朱批奏摺 } \\
\text { 分類立卷錄 }\end{array}$ \\
\hline yuezhe bao & 月摺包 \\
\hline yuezhe dang & 月摺檔 \\
\hline zhezi & 褶子 \\
\hline zouben & 奏本 \\
\hline
\end{tabular}


zouxiaodang

zouzhe
奏銷檔

奏摺

\section{Glossary 3. Other terms and phrases}

bao

Baqi dutong yamen

bulai

buxing

Cao Yin

chonfu

Cisinu

Da Qing Huidian

Da Qing lichao shilu

fanglüe

gongzhong

Guanglu si

ha-ha zhu-sai

ha-ha zhu-zi

hebi

jian

jinglai

jingxing

Junjichu

ke
包

八旗都統衙門

部來

部行

曹寅

重復

齊世武

大清會典

大清堐朝實錄

方略

宮中

光祿寺

哈哈珠塞

哈哈珠子

合壁

件

京來

京行

軍機處

科 
Li Xu

Lifanyuan

liubu

Menggutang

mifeng zouzhe

Neige

Neimishuyuan

quanzong

renming bao

shengxun

shiba da lei

shi-er zitou

Taichang si

taitou

"tongyi de duominzu guojia"

Tongzheng si

wanquan yizhi

"wu chaonong Hanren, yi jia jinshen"

xiangtong

xiunü

yao tilu

yileijia

zhen

zhidaoliao
李煦

理藩院

六部

蒙古堂

密封奏摺

內閣

内祕書院

全宗

人名包

聖訓

十八大類

十二字頭

太常寺

抬頭

統一的多民族國家

通政司

完全一致

無嘲弄漢人, 益加謹慎

相同

秀女

腰提爐

一類甲

朕

知道了 
Zongrenfu

zoushi chu

zuoling
宗人府

奏事處

佐領

\section{Selected References}

Amari Hiroki. "Heika shisho chū no heibu shōsho Gadafun nado no daihon ni tsuite" (The routine memorials of the Board of War president Gadafun in the Board of War shishu). Manzokushi kenkyū tsūshin 8 (1999), 10-25.

Bartlett, Beatrice S. "Books of Revelations: The Importance of the Manchu Language Archival Record Books for Research on Ch'ing History." Late Imperial China 6.2 (December 1985), 25-36.

. "Ch'ing Palace Memorials in the Archives of the National Palace Museum.” National Palace Museum Bulletin 13.6 (January-February 1979).

Chuang Chi-fa. Gugong dang'an shuyao (Description of archives in the National Palace Museum). Taipei: National Palace Museum, 1983.

- Qingdai zouzhe zhidu (The memorial system of the Qing dynasty). Taipei: Guoli gugong bowuyuan, 1979.

Crossley, Pamela Kyle and Evelyn S. Rawski. "A Profile of the Manchu Language in Ch'ing History." Harvard Journal of Asiatic Studies 53.1 (June 1993), 63102.

Da Qing gaozong chun (Qianlong) huangdi shilu (The veritable records of the Qianlong reign). Reprint ed. Taipei: Huawen shuju, 1964.

Elliott, Mark C. "Chūgoku dai'ichi rekishi tōankan shozō naikaku kyūchū Manbun tōan gaijutsu" (Outline of the Manchu holdings of the Grand Secretariat and Imperial Palace Archives at the First Historical Archives). Yanagisawa Akira, trans. Tōhōgaku 85 (1993), 147-157.

- The Manchu Way: The Eight Banners and Ethnicity in Late Imperial China. Stanford: Stanford University Press, 2001.

Fairbank, John K. and Ssu-yu Teng. "On the Transmission of Ch'ing Documents." Harvard Journal of Asiatic Studies (1940), 2-71.

First Historical Archives of China. Zhongguo diyi lishi dang'anguan guancang dang'an gaishu (Description of the holdings of the First Historical Archives of China). Beijing: Dang'an chubanshe, 1985. 
First Historical Archives, comp. Kangxi chao qijuzhu ce (Diaries of activity and repose from the Kangxi reign). 3 vols. Beijing: Zhonghua shuju, 1984.

- Qingdai zhupi zouzhe caizhenglei mulu (Catalogue of Qing palace memorials relating to financial matters). 5 vols. Beijing: Zhongguo caizheng jingji chubanshe, 1990-92.

. Yongzheng chao qijuzhu ce (Diaries of activity and repose from the Yongzheng reign). 5 vols. Beijing: Zhonghua shuju, 1993.

Fletcher, Joseph F. "Manchu Sources." In Donald Leslie, Colin Mackerras, and Wang Gungwu, eds., Essays on the Sources for Chinese History (Canberra: ANU Press, 1973), 141-146.

. "Review of Walter Simon and Howard G.H. Nelson, Manchu Books in London: A Union Catalogue." Harvard Journal of Asiatic Studies 41.2 (December 1981), 653-656.

Guan Xiaolian. "Qing Kangxi chao Manwen zhupi zouzhe chuyi” (Preliminary discussion of the Manchu palace memorials of the Kangxi reign). Lishi dang'an 1994.1, 84-90.

. "Zailun zouzhe qiyuan ji qi tedian" (Once again on the origins and special features of zouzhe). Paper delivered at the Second Conference on Ming-Qing Archives and Historical Research to Commemorate the $70^{\text {th }}$ Anniversary of the Founding of the First Historical Archives, Beijing, October 1995.

Hauer, Erich. "Why the Sinologue Should Study Manchu." Bulletin of the North China Branch of the Royal Asiatic Society 61 (1930), 156-164.

Hess, Laura E. "The Manchu Exegesis of the 'Lunyu'." Journal of the American Oriental Society 113.3 (July-September 1993), 402-17.

Institute of History, Chinese Academy of Social Sciences, comp. Qingshi ziliao (Sources for Qing history). Vol. 5. Beijing: Zhonghua shuju, 1984.

Ju Deyuan. "Qingdai tizou wenshu zhidu" (The communications system of the Qing). In Zhu Jinfu, ed., Ming-Qing dang'an lunwen xuanbian (Beijing: Dang'an chubanshe, 1985), 1004-1005.

Kanda Nobuo. "From Man-wen lao-tang to Chiu Man-chou tang." Memoirs of the Research Department of the Töyō Bunko 38 (1980), 71-94.

Kusunoki Yoshimichi. "Rika shisho chū no Rihan'in daihon" (Routine memorials from the Lifanyuan in the Board of Rites shishu). Manzokushi kenkyū tsūshin 5 (1995), 33-42. 
Legge, James, trans. The Chinese Classics, Vol. III: The Shoo King, or The Book of Historical Documents. Hong Kong: London Missionary Society, 1865.

Miyazaki Ichisada. "Shinchō ni okeru kokugo mondai no ichimen" (A look at the question of the national language during the Qing). Tōhōshi ronsō 1 (1947), 156.

Qu Liusheng. "Qingdai junjichu Manwen dang'an zongshu" (General outline of the Grand Council Manchu archives). Lishi dang'an 1989.1, 124-129.

Rawski, Evelyn S. The Last Emperors: A Social History of Qing Imperial Institutions. Berkeley and Los Angeles: University of California Press, 1999.

Sakurai Toshirō. "Mindai daisōhon seido no seiritsu to sono henyō" (The establishment and evolution of the Ming memorial system). Töyōshi kenkyū 51.2 (September 1992), 1-29.

Shibuya Kōichi. "Chūgoku dai'ichi rekishi tōankan shozō 'Mōkōdōtō' oyobi 'Manbun sōshoku' ni tsuite” (The Menggutang dang and Manwen zouchi in the First Historical Archives). Manzokushi kenkyū tsūshin 8 (1999), 21-31.

Spence, Jonathan D. Ts'ao Yin and the K'ang-hsi Emperor: Bondservant and Master. New Haven: Yale University Press, 1966.

Stary, Giovanni. Manchu Studies: An International Bibliography. 3 vols.

Wiesbaden: Kommissionsverlag Otto Harrassowitz, 1990.

Sugiyama Kiyohiko. "Chūgoku dai'ichi rekishi tōankanzō 'Rekichō hakki zatsutô' kanshō" (Brief introduction to the Lichao baqi zadang in the First Historical Archives). Manzokushi kenkyū tsüshin 8 (1999), 47-59.

Wilkinson, Endymion, ed. Chinese History: A Manual. Revised ed. Cambridge: Harvard University Asia Center, 2000.

Wu Yuanfeng. "Junjichu Manwen yuezhe bao ji qi zhengli bianmu" (The Grand Council Manchu yuezhe bao and their cataloguing). Qingshi yanjiu 1991.1, $61-64$.

—_ "Qingdai neige Manwen dang'an shulue" (Brief description of the Manchu archives of the Qing Grand Secretariat). Manxue yanjiu 2 (1994), 274-285.

$\mathrm{Wu}$, Silas H. L. Communication and Imperial Control in China: Evolution of the Palace Memorial System, 1693-1795. Cambridge: Harvard Council on East Asian Studies, 1970.

—. "The Memorial Systems of the Ch'ing Dynasty, 1644-1911." Harvard Journal of Asiatic Studies 27 (1965), 7-75. 
Yang Qiqiao. Yongzheng di ji qi mizhe zhidu yanjiu (The Yongzheng emperor and his secret memorials system). Hong Kong: Joint Publishing Company, 1981.

Zach, Erwin von. "Manchurian Translation of Lao-tzu's Tao-tê-ching." The China Review 25 (1900-1901), 157-162.

Zhu Jinfu. "Qingdai zouzhe zhidu kaoyuan ji qita" (Study of the beginnings of the Qing memorial system). In First Historical Archives, comp., Ming-Qing dang'an yu lishi yanjiu (Beijing: Zhonghua shuju, 1988), 520-523. 